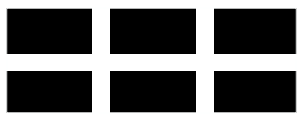

The WiLliam DAVIDSON Institute AT THE UNIVERSITY OF MICHIGAN BUSINESS SCHOOL

\title{
Effects of Ownership and Financial Status on Corporate Environmental Performance
}

\author{
By: Dietrich Earnhart and Lubomír Lizal
}

William Davidson Working Paper Number 492

August 2002 


\title{
Effects of Ownership and Financial Status on Corporate Environmental Performance
}

\author{
Dietrich Earnhart \\ University of Kansas \\ Centre for Economic Policy Research
}

Lubomír Lízal

CERGE-EI

\author{
Contact Information: \\ Dietrich Earnhart \\ Department of Economics \\ 213 Summerfield Hall \\ University of Kansas \\ Lawrence, KS 66045 \\ (785) 864-2866 \\ Earnhart@ku.edu
}

August 7, 2002

\begin{abstract}
This paper analyzes the effects of ownership structure on corporate environmental performance and examines the link from financial performance to environmental performance in a transition economy. In particular, it analyzes these ownership effects and this performance link using an unbalanced panel of Czech firms for the years 1993 to 1998. It considers state ownership and various types of private ownership, while contrasting concentrated and diffuse forms of private ownership. Additionally, it examines whether or not successful financial performance begets or undermines good environmental performance.
\end{abstract}

JEL codes: D21, G39, Q25, D62

Keywords: Czech Republic, environmental protection, pollution, ownership, financial status

* We acknowledge the financial support of a COBASE grant from the National Research Council. 


\section{William Davidson Institute Working Paper 492}

\section{Non-Technical Summary}

Recent economic analysis estimates the effects of different ownership structures on standard measures of corporate financial performance, such as revenue and capital investment, in the transition economies of Central and Eastern Europe (e.g., Frydman et al., 1999; Djankov, 1999; Claessens and Djankov, 1999). Our study estimates the effects of different ownership structures on corporate environmental performance, as measured by air pollutant emissions, in the transition economy of the Czech Republic during the years 1993 to 1998. In addition, we examine the link from financial performance to environmental performance.

Similar to previous studies on ownership, our analysis focuses on the effect of privatization, in other words, the comparison between state ownership and private ownership. Along these lines, we test the generally accepted hypothesis that private ownership generates better environmentallyrelated corporate performance. This hypothesis is based on the expectation that private owners more effectively reduce costs. Emissions represent costs because they generally indicate an inefficient use of inputs, generate emission charges (at least in our country of study), prompt greater need for costly end-of-pipe treatment when production management generates more residuals upstream in the production process, and induce regulatory authorities to impose potentially costly penalties, such as fines and requirements to modify production processes. As an alternative hypothesis, preferences for better environmental stewardship, independent of cost concerns, may differ by ownership structure. In this case, the state may express a greater concern for the environment by reducing emissions more strongly than private owners.

In addition, we examine variation across different types of private ownership. In particular, we distinguish between concentrated ownership (e.g., strategic investor) and diffuse ownership (e.g., investment fund) using three measures: (1) basic investor categories, (2) threshold level for reporting ownership shares, and (3) concentration measure based on the single largest shareholder. One might anticipate that more concentrated ownership permits owners to manage better costs, including environmentally-related costs. However, the expected effect of ownership concentration remains a theoretically unresolved issue.

Other recent economic analysis explores the links between corporate financial and environmental performance in mature market economies, especially the United States (e.g., Konar and Cohen, 2002; Gottsman and Kessler, 1998). Our study explores the effect of financial performance on environmental performance in the transition economy of the Czech Republic. In particular, our study determines whether successful financial performance begets or undermines good environmental performance. Successful financial performance may allow the firm to generate internal financial resources, which can be used to fund improvements in the firm's ability to reduce pollution. This generation of internal financial resources is probably more important in a transition economy such as the Czech Republic. As a matter of fact, internal financing is especially important for investment in the Czech Republic since Czech accounting standards and tax laws require firms to finance all investment with retained profits (Lizal and Svejnar, 2002a, b). 
Using a panel of Czech firms in the years 1993 to 1998, our analysis generates the following conclusions. First, successful financial performance improves future environmental performance. Second, greater state ownership actually improves environmental performance relative to all other investor types even though the state apparently retained ownership in more polluting industries. More specifically, after controlling for firm-specific fixed effects, increased state ownership significantly leads to better environmental performance. However, this conclusion depends on the treatment of firm-specific effects. If these effects are treated as random rather than fixed, the effect of state ownership on environmental performance is statistically insignificant.

Beyond the effect of state ownership, estimation results in general indicate that no type of private ownership significantly affects environmental performance. Individually and collectively, categories of private investors do not affect environmental performance differently than does the benchmark category of dispersed owners, who hold only a minor share of any single firm.

Overall, the estimation results indicate that the type of owner does not affect environmental performance as long as the analysis controls for production levels, sector-specific effects, and financial performance. In particular, financial performance seems to serve as the link from better ownership structure to improved environmental performance. Put differently, ownership structure does not directly affect environmental performance; it only indirectly affects environmental performance by influencing financial performance.

In contrast, concentrated ownership, as measured by the single largest shareholder, improves the environmental performance, consistent with the notion that concentrated power allows an owner to manage better costs, including environmentally-related costs. 
William Davidson Institute Working Paper 492

\section{Introduction}

Recent economic analysis estimates the effects of different ownership structures on standard measures of corporate financial performance, such as revenue and capital investment, in the transition economies of Central and Eastern Europe (e.g., Frydman et al., 1999; Djankov, 1999; Claessens and Djankov, 1999). Our study estimates the effects of different ownership structures on corporate environmental performance, as measured by air pollutant emissions, in the transition economy of the Czech Republic during the years 1993 to 1998. In addition, we examine the link from financial performance to environmental performance. ${ }^{1}$

Similar to previous studies on ownership, our analysis focuses on the effect of privatization, in other words, the comparison between state ownership and private ownership. Along these lines, we test the generally accepted hypothesis that private ownership generates better environmentallyrelated corporate performance. This hypothesis is based on the expectation that private owners more effectively reduce costs. Emissions represent costs because they generally indicate an inefficient use of inputs, generate emission charges (at least in our country of study), prompt greater need for costly end-of-pipe treatment when production management generates more residuals upstream in the production process, and induce regulatory authorities to impose potentially costly penalties, such as fines and requirements to modify production processes. ${ }^{2}$ As an alternative hypothesis, preferences for better environmental stewardship, independent of cost concerns, may differ by ownership

\footnotetext{
${ }^{1}$ Other recent economic studies of environmental issues in the Czech Republic focus on government regulatory decisions rather than firm performance (Earnhart, 2000a; Earnhart, 2000b; Earnhart, 1997).

${ }^{2}$ Of course, state-owned firms may feel less to pressure to control emissions if state regulators are reluctant to impose fees, charges, and penalties on state-owned firms.
} 
William Davidson Institute Working Paper 492

structure. In this case, the state may express a greater concern for the environment by reducing emissions more strongly than private owners.

In addition, we examine variation across different types of private ownership. In particular, we distinguish between concentrated ownership (e.g., strategic investor) and diffuse ownership (e.g., investment fund) using three measures: (1) basic investor categories, (2) threshold level for reporting ownership shares, and (3) concentration measure based on the single largest shareholder. One might anticipate that more concentrated ownership permits owners to manage better costs, including environmentally-related costs. To support this view, Shleifer and Vishny (1997) argue that ownership concentration results in better monitoring of managers. Similarly, Admati et al. (1994) argue that the "free-riding of minor shareholders" in the decision process of corporate governance may undermine firm performance. On the other hand, concentrated ownership may harm firm performance. For example, Agion and Tirole (1997) argue that highly uncertain business conditions may require managerial initiative and incentives to acquire information. Concentrated ownership may thwart these efforts. Similarly, Bolton and von Thadden (1998) claim that dispersed ownership might be optimal if shareholders are able to block unwanted but necessary restructuring. Concentration may also proxy for multi-objective maximization, which could include preferences for better environmental stewardship, on the part of owners or managers as opposed to the simple model of single-criterion profit maximization (Furubotn and Pejovich, 1972; Hart and Moore, 1990). Therefore, the expected effect of ownership concentration remains an unresolved issue. Given that both positive and negative effects may exist in reality, our empirical analysis may not effectively identify any dominant pattern. 
William Davidson Institute Working Paper 492

Other recent economic analysis explores the links between corporate financial and environmental performance in mature market economies, especially the United States (e.g., Konar and Cohen, 2002; Gottsman and Kessler, 1998). Our study explores the effect of financial performance on environmental performance in the transition economy of the Czech Republic. In particular, our study determines whether successful financial performance begets or undermines good environmental performance. Successful financial performance may allow the firm to generate internal financial resources, which can be used to fund improvements in the firm's ability to reduce pollution. This generation of internal financial resources is probably more important in a transition economy such as the Czech Republic. As a matter of fact, internal financing is especially important for investment in the Czech Republic since Czech accounting standards and tax laws require firms to finance all investment with retained profits (Lízal and Svejnar, 2002a, b).

This paper attempts to answer the questions and test the hypotheses posed above within the following format. The next section notes the key features of the related economic literature. Section 3 describes the database on corporate financial performance, ownership structure, and air emissions. Section 4 estimates and interprets the effects of ownership and financial performance on corporate environmental performance. The final section summarizes.

\section{Related Economic Literature}

\subsection{Effects of Ownership Structure on Corporate Performance}

Recent economic analysis estimates the effects of different ownership structures on standard measures of corporate financial performance in the transition economies of Central and Eastern Europe (CEE). Frydman et al. (1999) compares the performance of privatized and state firms in the 


\section{William Davidson Institute Working Paper 492}

transitional economies of Central Europe by examining growth rates in key financial indicators. ${ }^{3}$ In particular, they examine sales revenues, employment, labor productivity, and labor and material costs (relative to revenues). They show that privatization has different effects on financial performance depending on the types of owners who gain control. In particular, outsiders but not insiders generate significant performance effects. ${ }^{4}$

Djankov (1999) explores the relationship between ownership structure and enterprise restructuring in six Newly Independent States. He finds differences across the type of private ownership. Foreign ownership generates enterprise restructuring at high levels of ownership. Manager ownership leads to enterprise restructuring at low or high levels of ownership but not at intermediate levels. Outside local investors do not significantly affect enterprise restructuring.

Claessens and Djankov (1999) explore the relationship between the composition of ownership and corporate financial performance in the Czech Republic. Examining the period 1992 through 1997, they reveal that more concentrated ownership leads to higher firm profitability and greater labor productivity.

Kocenda and Svejnar (2002) also analyze the effect of ownership on post-privatization corporate financial performance in the Czech Republic. They reject the notion that domestic or

${ }^{3}$ Due to the limited time frame of our study, we chose not to examine the growth rates for environmental performance.

${ }^{4}$ Our database does not distinguish between outsiders and insiders. Fortunately, due to the Czech privatization methods, no significant insider ownership is expected. Claessens and Djankov (1999) report that the Czech voucher scheme prevented insiders from acquiring large ownership stakes since few direct sales of assets took place before the voucher privatization. Indeed, the ownership database used for this study contains almost no records of employee ownership. Kocenda and Svejnar (2002), who utilize a similar data source, report this same feature of the ownership data. Also, the recording of managerial ownership is mostly limited to the design of the large scale privatization scheme when the managers were required by the privatization law to prepare at least one privatization project. For detailed descriptions of the Czech (and Czechoslovak) privatization process and its outcomes, see Kotrba (1995) and Kotrba (1997). 
William Davidson Institute Working Paper 492

foreign private ownership leads to increased sales. Instead, they find that private domestic and foreign majority owners, as well as significant minority owners, increase profitability relative to state-owned firms. Firms with dispersed ownership generate even higher profits than firms with more concentrated ownership; this result supports theories that stress managerial autonomy and initiative. When domestic banks or portfolio companies represent the single largest owner, firms are generally incapable of carrying out major restructuring.

Megginson and Netter (2001) provide a comprehensive survey of other empirical studies on privatization. This survey demonstrates that several studies examine corporate financial performance. However, to the best of knowledge, no published studies examine the effects of ownership structure, privatization in particular, on corporate environmental performance.

\subsection{Links between Financial and Environmental Performance}

Other recent economic analysis explores the links between corporate financial and environmental performance. All of these studies analyze firms in mature market economies. The first set of studies explore only the link from environmental performance to financial performance. As one example, Konar and Cohen (2002) explore the link from environmental performance to financial performance as captured by a firm's market value. After controlling for variables traditionally thought to explain corporate financial performance, they demonstrate that bad environmental performance is negatively correlated with market value. In particular, a $10 \%$ reduction in toxic chemical emissions causes a \$ 34 million increase in market value.

Gottsman and Kessler (1998) also explore the link from environmental performance to financial performance. They compare the financial returns to the S\&P 500 against three sub-samples based on four measures of environmental performance. In particular, they divide firms into the top 
William Davidson Institute Working Paper 492

$75 \%$, top $50 \%$, and top $25 \%$ of environmental performers across all industries. They find no statistically significant differences in financial performance between the three categories of environmental performers.

Bosch et al. (1998) explore the effect of federal environmental enforcement, which represents one measure of environmental performance, on stockholder wealth. They show that the stock market reacts negatively upon learning that a given firm has been targeted for enforcement.

Klassen and McLaughlin (1996) examine the link between signals of strong environmental management, as measured by environmental performance awards, and firms' equity returns; they also examine the link between signals of weak environmental management, as measured by environmental "crises", and firms' equity returns. They demonstrate that signals of strong management increase equity returns, while signals of weak management lower equity returns.

Austin et al. (1999) also explore the link from environmental performance to financial performance. More important to our research, they explore the link from financial performance to environmental performance. In particular, they seek to identify the causal relationship between these two types of performance by employing sample means tests and regression analysis. In the context of sample means tests, they divide firms into "green" and "brown" categories to test the differences in financial performance mean values. Conversely, they divide firms into "black" and "red" categories, according to financial performance, to test the differences in environmental performance mean values. In the regression context, they regress financial performance on lagged environmental performance and regress environmental performance on lagged financial performance. Their results provide strong evidence of a relationship existing between environmental and financial performance but cannot strongly identify the direction in which causality runs. 


\section{William Davidson Institute Working Paper 492}

Our study draws upon both of these economic research strains to examine the effect of ownership structure on corporate environmental performance and to explore the link from financial performance to environmental performance in the transition economy of the Czech Republic.

\section{Data on Financial and Environmental Performance and Ownership Structure}

\subsection{Czech Republic as Study Site}

To examine the effects of ownership structure and explore the link from financial to environmental performance, we exploit data on firms in the Czech Republic, which is an excellent site for our study. First, this transition economy possesses a highly interesting pattern of ownership structures due to the chosen privatization methods, especially the extensive use of citizen vouchers (Weiss and Nikitin, 2002). Second, most Czech enterprises have been privatized, yet some key sectors in our study remain heavily state-controlled. For example, all utilities, especially energy utilities, were state-controlled throughout the period examined. ${ }^{5}$ Therefore, our study is able to examine the distinction between wholly state-owned firms and privatized firms for the entire sample period. Even when state-owned enterprises have been privatized, the state still maintains significant influence. Kocenda (1999) shows that the state is able to influence over $76 \%$ of the total assets using three means: (1) primary ownership, (2) veto power of "golden shares", and (3) secondary ownership (i.e., the firm is owned by a state-controlled firm). ${ }^{6}$ Since our study measures the share of state

5 A utility company is a typical example of a "strategic company" that the state controls with veto power based on "golden shares", according to Kocenda (1999).

${ }^{6}$ As another indicator of the state's influence across the Czech economy, the total book value of the shares (assets) held directly by the National Property Fund is still even larger than the book value of shares that were subject to the voucher privatization (Kocenda, 1999). 


\section{William Davidson Institute Working Paper 492}

ownership, we are able to capture this state influence over privatized firms as a means of examining the distinction between state and private ownership in more general terms.

Third, several previous studies examine the effect of ownership on standard measures of corporate financial performance in the Czech Republic (e.g., Claessens and Djankov, 1999). Thus, we are able to compare our results on environmentally-related corporate performance to others' results on standard performance measures.

Fourth, the Czech Republic has a substantially degraded environment; in particular, poor ambient air quality and air pollution is a large environmental problem of public concern in the Czech Republic (World Bank, 1992). In response to public concern, the Czech government has taken strong and successful steps to reduce air emissions substantially during the period 1991 to 1998 (Czech Ministry of Environment, 1998). Figure 1 displays the trend of air emissions over this period. ${ }^{7}$ While an overall decline in economic activity and reduced energy demand certainly explain part of this decline, pollution control laws (e.g., 1991 Czech National Air Act) and firms' pollution control efforts, such as installation of electrostatic precipitators ("scrubbers") and fuel switching, also explain much of this decline (World Bank, 1999). Fifth, the Czech government is currently seeking to enter the European Union (EU) and must reduce industrial emissions to qualify for membership. These efforts dovetail with efforts to allay public concern over air quality. ${ }^{8}$

\footnotetext{
${ }^{7}$ Nitrous oxide $\left(\mathrm{NO}_{\mathrm{x}}\right)$ emissions do not demonstrate as strong a downward trend due to the rapid rise in automobile ownership and use.

${ }^{8}$ Further details on country-wide emissions, Czech air regulations, and environmental issues related to EU accession are available upon request.
} 
William Davidson Institute Working Paper 492

\subsection{Panel Data from Financial Statements, Ownership Files, and Emissions Register}

To examine financial performance and ownership structure at Czech enterprises, we gather data from three segments of a database provided by the private data vendor Aspekt. One segment provides information drawn from firms' balance sheets, such as asset levels, and information taken from firms' income (profit/loss) statements, such as profits. The second (smaller) segment provides information on ownership structure. We gather balance sheet and income statement data for the years 1993 to 1999 and ownership data for the years 1994 to 1999. The Aspekt database includes all firms traded on the Prague Stock Exchange, publicly traded firms [i.e., firms registered for trading on the RMS (Registra_ní místo system) secondary market], and a majority of the remaining large Czech firms (plus the key trading partners of these large firms). Since all firms that underwent voucher privatization were publicly traded at the beginning of the privatization process, these firms represent the majority of the firms included in the Aspekt database.

As an indicator of corporate environmental performance, we chose air pollutants emitted by Czech entities for the years 1982 and 1998. The included pollutants are carbon monoxide (CO), sulfur dioxide $\left(\mathrm{SO}_{2}\right)$, particulate matter, and nitrous oxides $\left(\mathrm{NO}_{\mathrm{x}}\right)$, which represent the main and most heavily regulated pollutants in the Czech Republic, similar to other industrialized nations. The Czech Hydrometeorological Institute maintains four databases on air emissions by four types of polluters. The REZZO-1 database records emissions for large, stationary sources. The REZZO-2 database records emissions for medium-sized, stationary sources. The REZZO-3 and REZZO-4 databases record emissions for mobile and household sources, respectively. We use the REZZO-1 database for our analysis, which, by its nature, should have the largest overlap with the financial and ownership data we possess. The REZZO-1 database records emissions at individual units of 


\section{William Davidson Institute Working Paper 492}

individual facilities. The Czech Hydrometeorological Institute aggregates the air emissions to the level of each facility before public release of the data. We further aggregate air emissions across all facilities associated with a single firm (i.e., we attribute the aggregated emissions to a single firm). Finally, we add the four pollutants into one composite measure of air emissions. ${ }^{9}$

In order to generate the largest sample possible and to avoid a sample selection bias due to attrition, we create an unbalanced panel of firm-year observations for the time period 1993 to 1998. First, we merge the data from the balance sheet and income statement files into a financial data set that covers the years 1993 to 1999 with 37,601 observations representing 10,102 firms. Second, we add air emissions data that covers the period 1993 to 1998 with 9,703 observations. The overlap between the financial data set and the air emissions data set is quite limited. The two data sets only hold 4,688 observations in common. ${ }^{10}$ Third, we screen for meaningful financial data by applying the following criteria: positive production (measured in thousands of Czech Crowns), positive total assets, and non-negative fixed assets. ${ }^{11}$ We also restrict our sample to those observations with nonmissing data for key financial and emission variables. This screening and restriction generates an unbalanced panel of 2,628 observations, which covers the years 1993 to 1998 . We use this sample

9 Estimation of the individual pollutants generates results that are similar or less significant than those results chosen for interpretation. Tables A-1 of Appendix \# 1reports the majority of these individual pollutant results. Complete results are available upon request.

${ }^{10}$ While unfortunate, this limited overlap does not indicate a problem with the data. Instead, it may simply indicate that firms included in the Aspekt database own medium rather than large stationary air emission sources or own facilities that lack the need to measure air emissions because such emissions are nonexistent or extremely low. In this way, the Aspekt database need not completely represent large stationary air polluters. Therefore, our results may not generalize to all or most large stationary air polluters. The opposite concern is not relevant. The REZZO-1 database is fully comprehensive of all large polluters.

${ }^{11}$ Other important financial measures, such as profits, are difficult to screen because they can truthfully take zero or negative values. 


\section{William Davidson Institute Working Paper 492}

initially to estimate the link from financial performance to environmental performance. (As explained below, our econometric models use lagged rather than current profits as a regressor. This restriction drops the sample size to 2173 observations representing 564 firms.)

To estimate the effect of ownership structure, we add ownership information that covers the years 1993 to 1999 with 15,804 observations representing 5,811 firms. A merger between the financial-emission data set and the ownership data set generates a combined unbalanced panel of 463 firms with 1127 observations. Obviously, we lack ownership data for many firm-year observations. (In particular, ownership information is less well recorded for the years 1993 to 1995.) The data vendor Aspekt constructs the ownership data using four sources of information. First, the Prague Stock Exchange (PSE) maintains a Register of Shares for all listed companies. All stockholdings above $10 \%$ for individual investors are made publicly available. ${ }^{12}$ Second, companies provide ownership data via their annual reports and stockholder meeting reports as required by the relevant stock exchange and/or court of registry. Third, the data vendor sends questionnaires to firms requesting ownership information. Fourth, the data vendor draws upon published materials, e.g., newspaper articles. While the first two information sources need not generate a selection bias, the latter two sources may do so. We address this potential issue of sample selectivity by implementing a Heckman two-step sample selection procedure.

\subsection{Descriptive Statistics}

Table 1 presents a statistical summary of the relevant firm characteristics. As shown in Table 1.A, our data are sufficiently spread across the three years of our time frame. Table 1.C indicates the

${ }^{12}$ Investment funds, portfolio investors, and the state (i.e., holdings by the National Property Fund and the Restitution Fund) often publish the composition of their portfolio, which makes information on smaller holdings publicly available. 


\section{William Davidson Institute Working Paper 492}

distribution of firms by industrial classification. Our data set contains very few observations on certain industries: agriculture and forestry, mining, and transport. These industries, by the nature of their production processes, are not expected to be major stationary air polluters.

Table 1.B presents a statistical summary of the remaining firm characteristics. First, it summarizes the key financial variables used in our study: profits, production value, fixed assets. As demonstrated by the standard deviation measures, our data set contains much variation in these financial measures, which will facilitate our estimation. Table 1.B also summarizes the measures of air emissions, which are measured in tons per year. As with the financial measures, our data set contains much variation for each pollutant and all pollutants combined, as measured by standard deviation values.

Table 1.B also presents a summary of ownership structure. Our data set identifies the ownership shares held by certain types of investors:

(1) state,

(2) investment funds,

(3) citizens,

(4) portfolio companies,

(5) bank (direct ownership),

(6) strategic investors (other companies),

(7) foreign investors, and

(8) dispersed private investors (not included in the Table).

Portfolio companies are similar to strategic investors in that another company invests in the identified company; however, the rationale for the investment ranges from hedging to improvement 


\section{William Davidson Institute Working Paper 492}

in governance to asset stripping. The category of dispersed investors includes investors who hold less than $10 \%$ of a given company and never publicly announced their holdings. (This category contains few holdings by investment funds, portfolio companies, and the state.) Since these shares are not publicly available (unless announced by the relevant investors), we cannot measure the presence of this category directly. Instead, we establish it as the omitted category in our regression analysis. As a benchmark, these investors clearly represent less interested, non-strategic investors since they hold such a small share of the particular company. (Given the reporting threshold of 10\% for individual investors, it will be difficult to capture citizen ownership in our database of mostly larger firms.)

As shown in Table 1.B., the state retains a sizeable presence in the average firm and strategic investors seem to dominate the average firm. To explore the hypotheses related to ownership effects, we use the state category as the benchmark for examining the effect of privatization. Moreover, we identify strategic and foreign investors as concentrated ownership forms and banks, investment funds, citizens, and dispersed investors as diffuse ownership forms (while acknowledging that citizens may differ from business entities in meaningful ways). ${ }^{13}$ As a matter of fact, dispersed investors represent the most "diffuse" ownership type since each investor holds only a very small share of the firm. Although portfolio companies most likely represent concentrated ownership, given

${ }^{13}$ Czech legislation prohibits investment funds from owning more than $20 \%$ of any particular company. Nevertheless, some investment funds illegally agree to transfer decision rights amongst themselves or illegally coordinate their actions. 
William Davidson Institute Working Paper 492

the broad range of investment motives, the expected effect of portfolio investment is ambiguous. In addition to ownership shares, we create a variable to capture the concentration of ownership as measured by the stockholding share of the single largest shareholder (Ko_enda and Svejnar, 2002).

Ownership structure varies substantially by industrial sector as mentioned in Section 3.1 and

described in Table 1.D. For example, the electricity, mining, and oil refining sectors are heavily state-influenced, while the rubber and plastic sector shows no state influence. More important for the econometric analysis, within any given sector, certain investor categories are weakly represented if at all. Once the econometric analysis controls for industry-specific effects (or firm-specific effects), it may be difficult to establish any statistical significance for the marginal effects of ownership structure.

\section{Econometric Analysis of Environmental Performance}

In this section, we use the described data to explore the link from financial to environmental performance and the effect of ownership structure on environmental performance at Czech firms.

\subsection{Estimate Effect of Financial Performance on Environmental Performance}

We estimate the relationship between environmental performance and key explanatory variables using standard unbalanced panel analysis. When examining the link from financial to environmental performance, we avoid using current financial performance, since contemporaneous financial and environmental performance are most likely jointly determined. Instead, we use lagged financial performance, which is considered as predetermined, e.g., Lízal and Svejnar (2002a,b). Thus, lagging financial performance avoids any endogeneity problem (Austin et al., 1999). Moreover, one would expect a lag between the generation of financial resources and the ability to 


\section{William Davidson Institute Working Paper 492}

invest in ways of reducing air emissions. ${ }^{14}$ This generation of internal financial resources is probably more important in a transition economy such as the Czech Republic. As a matter of fact, internal financing is especially important for investment in the Czech Republic since Czech accounting standards and tax laws require firms to finance all investment with retained profits (Lízal and Svejnar, 2002a,b).

It is debatable whether estimation of corporate environmental performance should include or exclude the lagged dependent variable as a regressor. On the side of inclusion, the lagged dependent variable serves as a possible proxy for the type of treatment technology employed at specific facilities. It also captures the inertia most likely inherent in any production and treatment process (Magat and Viscusi, 1990); facilities most likely require several months, if not years, to modify their production and treatment systems. However, these long-run aspects should be completely (and more precisely) captured by firm-specific fixed effects, which represents one econometric approach for estimating the unbalanced panel data.

On the side of exclusion, the lagged dependent variable is potentially correlated strongly with other important explanatory variables, in particular, lagged financial performance and current ownership structure, especially when ownership changes little from year to year. Once we accept the reasons for inclusion of the lagged variable, we should also acknowledge the existence of autocorrelated disturbances since the arguments are quite similar: installation of a given technology does not permit quick modification, which implies that the error term is likely to be autocorrelated.

Most important, inclusion of the lagged dependent variable brings up non-trivial problems in the panel setup, especially when unobservable fixed effects are potentially correlated with the error

\footnotetext{
${ }^{14}$ In Appendix \# 2, we test the Granger causality between profits and emissions.
} 


\section{William Davidson Institute Working Paper 492}

term. For our analysis, we primarily use a fixed effect model to control for any individual differences across the firms in our analysis. Fixed effects estimation that includes the lagged dependent variable, when disturbances are autocorrelated, leads also to inconsistent estimates. While certain econometric methods, such as instrumental variables (IV) and general method of moments (GMM), address these issues, the existing methods rely on large sample properties (Anderson and Hsiao, 1982, Arellano and Bond, 1991). The small sample properties of these methods are still being examined (Bun and Kiviet, 1999, Harris and Matyas, 1996). Indeed, Bun and Kiviet (1999) show that use of IV methods can generate a severe bias in relatively small samples. ${ }^{15}$ While inclusion of the lagged dependent variable as a regressor would capture any potential dynamics in the evolution of environmental performance over time, any other benefits of inclusion are rather small compared to the enormous increase in complexity and potential bias associated with the noted econometric methods. Therefore, we choose not to include the lagged dependent variable as a regressor.

We estimate environmental performance in two forms: (1) absolute emissions and (2) emissions relative to production (hereafter "relative emissions"). To generate relative emissions, we simply divide the absolute emissions level by the production level. Both forms plausibly capture corporate environmental performance. And both forms are relevant for the Czech legal framework. Czech government regulators impose both quantity-based limits (e.g., tons per month) and concentration-based limits (e.g., grams of pollutant per liter of air). Quantity-based limits relate directly to absolute emissions. Concentration-based limits relate roughly to relative emissions as

${ }^{15}$ Our time span is only five periods at most. Inclusion of the lagged dependent variable reduces the time dimension by using at least one period for the lagged value and yet another one for instruments in the estimation (or lagged differences). The remaining three time periods are insufficient for IV methods of estimation. 
William Davidson Institute Working Paper 492

long as the level of production is proportional to the volume of air flowing out a facility's smokestacks. $^{16}$

Each form has its advantage. If one's main concern is environmental protection, then absolute emissions is the proper form since environmental degradation depends on the mass of pollutants not its ratio to production. In contrast, relative emissions may better capture the environmental stewardship provided by a given firm. Arguably, a firm with high absolute emissions and high production might be more environmentally friendly than a firm with lower absolute emissions but very small production. In addition, use of relative emissions permits a more direct calculation of economies of scale between production level and pollution control. If economies of scale exist, then increases in the production level should lower relative emissions. In other words, the pollution control process becomes more efficient with increasing production.

To construct the econometric models associated with these two forms of corporate environmental performance, we define the following notation. As the dependent variable, $p_{\text {it }}$ denotes the amount of pollution emitted by firm $i$ in time period $t$. As the primary explanatory variable, $\pi_{i, t-1}$ denotes the profits generated by firm $i$ in the preceding time period $t-1$ (i.e., lagged profits). We include other explanatory variables. Environmental performance most likely depends strongly on the level of production, which is denoted as $y_{\mathrm{it}}$. To capture the effect of firm size, we include fixed assets, which are denoted as $a_{\mathrm{it}}$. To control for variation over time with respect to economy-wide

16 We do not possess information on facility-specific limits. This omission should not be problematic. First, limits are frequently assigned for an entire sector. When including sector indicator variables as regressors, we control for limit variation across sectors. Second, when including firm-specific effects as regressors, we control for limit variation across firms. Third, by including year indicator variables as regressors, we control for limit variation in general across time. Fourth, the Czech air regulations do not explicitly include ownership structure or financial performance as factors for guiding the establishment of limits. Thus, limits are not expected to be correlated with our two key factors for explaining emissions. 


\section{William Davidson Institute Working Paper 492}

trends and the legal framework controlling air emissions, we also include individual year indicators (introduced later), collectively denoted as vector $T_{\mathrm{it}}$. In certain specifications, we include industry indicator variables, which control for sector-specific variation; on average, firms in certain sectors may be more polluting than firms in other sectors. These industrial dummy variables are collectively denoted as vector $X_{i t}{ }^{17,18}$

Given this notation, the two basic econometric models are formulated as follows:

$$
\begin{array}{ll}
\text { Model 1: } & \mathrm{p}_{\mathrm{it}}=\alpha \mathrm{a}_{\mathrm{it}}+\gamma \mathrm{y}_{\mathrm{it}}+\beta \pi_{\mathrm{i}, \mathrm{t}-1}+\mathrm{e}_{\mathrm{it}}, \\
\text { Model 2: } & (\mathrm{p} / \mathrm{y})_{\mathrm{it}}=\delta \mathrm{a}_{\mathrm{it}}+\eta \mathrm{y}_{\mathrm{it}}+\theta \pi_{\mathrm{i}, \mathrm{t}-1}+\mathrm{u}_{\mathrm{it}},
\end{array}
$$

where $e_{\text {it }}$ and $u_{\text {it }}$ denote the respective error terms.

In each of these models, the error term is most likely heteroskedastic. To correct this problem, we assume that this heteroskedasticity depends solely on firm size: $\sigma_{\text {it }}=\sigma \cdot a_{\mathrm{it}}$, where $\sigma_{\mathrm{it}}$ represents the standard error associated with the residual term $e_{i t}$ or $u_{\text {it }}$. To increase the efficiency of our estimation when correcting for heteroskedasticity, we multiply equations (1) and (2) by the inverse of fixed assets: $1 / a_{\mathrm{it}}$. The subsequent equations are denoted as Models $1 \mathrm{~A}$ and $2 \mathrm{~A}:{ }^{19}$

${ }^{17}$ Each year indicator variable does not vary across the firms and each industrial dummy variable does not vary across time for the same firm.

${ }^{18}$ Surely other factors, such as fuel composition and treatment technologies, explain variation in air emissions. However, given our focus on air emissions aggregated across all facilities within a firm and summarized across the four major pollutants, these more specific factors are probably less important than corporate-level production levels and financial status. Moreover, incorporation of firm-specific effects will control for more particular factors like treatment technology as long as these factors do not develop differently over the sample period; note that year indicator variables capture any common trends.

19 In Model 1A, emissions are expressed as kilograms per $1000 \mathrm{CZK}$ of fixed assets. In Model 2A, emissions are expressed as milligrams per $1000 \mathrm{CZK}$ of fixed assets and $1000 \mathrm{CZK}$ of production, i.e., $\left[\mathrm{mg} /(1000 \mathrm{CZK})^{2}\right]$. 
William Davidson Institute Working Paper 492

$$
\begin{aligned}
& \text { Model 1A: } \quad(\mathrm{p} / \mathrm{a})_{\mathrm{it}}=\alpha+\gamma(\mathrm{y} / \mathrm{a})_{\mathrm{it}}+\beta\left(\pi_{\mathrm{i}, \mathrm{t}-1} / \mathrm{a}_{\mathrm{it}}\right)+\Psi{ }^{\prime} \mathrm{T}_{\mathrm{it}}+\varepsilon_{\mathrm{it}}, \\
& \text { Model 2A: } \quad[(\mathrm{p} / \mathrm{y}) / \mathrm{a}]_{\mathrm{it}}=\delta+\eta(\mathrm{y} / \mathrm{a})_{\mathrm{it}}+\theta\left(\pi_{\mathrm{i}, \mathrm{t}-1} / \mathrm{a}_{\mathrm{it}}\right)+\kappa^{\prime} \mathrm{T}_{\mathrm{it}}+\mathrm{v}_{\mathrm{it}},
\end{aligned}
$$

where $\varepsilon_{\mathrm{it}}$ and $\mathrm{v}_{\mathrm{it}}$ are the corrected error terms. This correction for heteroskedasticity proves quite helpful. The correction causes the Lagrange multiplier (LM) heteroskedasticity test statistic to fall dramatically from triple digits to single digits for each specification considered. ${ }^{20}$

To control properly for firm-specific effects, we estimate Models 1A and 2A using standard panel methods: pooled OLS, between group estimation, fixed effects method, and random effects method. ${ }^{21}$ We use standard tests to assess these methods. When the F-test indicates significant individual effects, the fixed effects estimator dominates pooled OLS. Since this dominance always holds, we only report the pooled OLS estimates for the sake of comparison. We use the Hausman test of fixed effects to evaluate whether we could use more efficient random estimates or whether these estimates are inconsistent when compared to the fixed effects. When the Hausman test signals that the random effects estimator is consistent with the fixed effects estimator, the random effects estimator is preferable since it is more efficient by construction. We report the between group estimator only to decompose and assess the random effects estimates.

Table 2 presents the regression results for Models 1A and 2A. For both models, the F-test statistic for individual fixed effects indicates that the fixed effects estimator dominates the pooled

20 The specific test statistic values are available upon request. As an example, in the pooled OLS specification, the heteroskedasticity test statistic value drops from 283 for Model 1 to 9 for Model 1A. In general, the heteroskedasticity test still signals the presence of heteroskedasticity. Thus, we always report the heteroskedastic-consistent (corrected) standard errors for our estimates.

21 The between group estimator calculates the mean value of the dependent and independent variables for each firm and then estimates the model based on these mean values. In the fixed effect estimator, the intercept terms are specific to each firm $i: \alpha_{\mathrm{i}}$ and $\delta_{\mathrm{i}}$. 


\section{William Davidson Institute Working Paper 492}

OLS estimator for both models, while the Hausman test statistic indicates that the random effects estimator dominates the fixed effects estimator in the case of absolute emissions (Model 1A), while the opposite holds in the case of relative emissions. For both models, based on the random effects estimates, the effect of lagged financial performance is significantly negative, indicating that stronger financial performance leads to better future environmental performance (i.e., lower emissions). For Model 2A, based on the fixed effects estimates, this effect is also significantly negative. Therefore, financial success begets better environmental performance.

By comparing the between group and fixed effect estimation results, we conclude that the effect of financial performance within a firm explains relatively more of the variation in environmental performance than does the effect of financial performance across firms. The financial performance coefficient based on between group estimation is strongly significant for both models, while the same coefficient based on fixed effects estimation is insignificant in Model 1A and only significant at the $5 \%$ level in Model 2A. (For both the between group and fixed effects estimation results, the effect of lagged financial performance on current emissions is negative.)

Production also significantly affects environmental performance. Higher production significantly increases absolute emissions, as expected, and relative emissions, which implies that the average firm faces diseconomies to scale between production and pollution control.

These conclusions are robust to the inclusion of industrial indicators variables.

Models $1 \mathrm{~A}$ and 2A ignore the effects of ownership structure. The next sub-section incorporates these effects into our estimation of corporate environmental performance. 
William Davidson Institute Working Paper 492

\subsection{Explore Effects of Ownership Structure on Corporate Environmental Performance}

Next, we explore the effects of ownership structure on corporate environmental performance. To estimate the effects of ownership structure, we employ a synchronic approach, which controls for macroeconomic or sectoral conditions by examining various firms under similar circumstances. To implement this approach, we compare across firms, while including year and firm-specific fixed effects (or industry indicator variables). ${ }^{22}$

Before incorporating ownership effects into the estimation of corporate environmental performance, we must address the concern over the incomplete recording of ownership structure data. As noted above, the data vendor records ownership data for only a portion of the firms available in the financial database. While the decision to record ownership data most likely does not bias our results, we implement the standard Heckman two-step procedure to correct for any potential sample selection bias (Heckman, 1979). As the first step, we use a Probit model to estimate the probability of ownership data being recording. As regressors in this model, we include the following current corporate financial characteristics: total assets, fixed assets, log of fixed assets, fixed assets squared, production, production squared, log of production, profit, and log of the absolute value of

${ }^{22}$ Unfortunately, this approach potentially involves a selection bias caused by the state possibly privatizing only selected firms because they are "better" in some sense (Frydman et al., 1999, Gupta et al., 2000). Most likely, this selection process depended on financial characteristics. Of course, environmental characteristics may have played a role too. If true, this selection upwardly biases the effect of privatization in that environmentally cleaner facilities were privatized. In the Czech Republic, a substantial portion of investor's concerns involving environmental matters focused on legal responsibility for remediating ("cleaning up") on-site contamination caused by previous wastewater discharges and hazardous waste disposal (Earnhart, 2000c). By 1993, these concerns were addressed by a Czech policy to relieve investors of practically all these legal responsibilities (Earnhart, 2000c). Current, on-going air emissions were most likely less important. Even if current, on-going air emissions were important, investors most likely focused on absolute emissions not relative emissions. Thus, estimation of relative emissions most likely avoids the selection bias all together. Lastly, use of a fixed effects estimator should control for any non-random selection with respect to privatization (Frydman et al., 1999). 


\section{William Davidson Institute Working Paper 492}

profit times the sign of profit. In addition, we include industrial and year indicator variables. This flexible form hopefully approximates any decisionmaking process that is based on the firm's size, technology, and profitability. The Probit model correctly predicts the recording of ownership data with a $83 \%$ success rate. ${ }^{23}$ Based on the coefficient estimates, we generate an inverse Mills ratio for each firm $i$ in time period $t$, denoted as $\lambda_{\mathrm{it}}$. By including this variable as a regressor in the estimation of corporate environmental performance, we control for any potential sample selection bias.

To incorporate the effects of ownership structures into our estimation of environmental performance, we include various additional regressors. First, we include a regressor for each ownership type except "dispersed investors". As noted above, we use this omitted category as the baseline for interpreting the effects of the remaining ownership types. Collectively, we denote these ownership variables as $W_{\text {it }}$. Second, we include a measure of concentration, as captured by the ownership share held by the single largest shareholder and denoted as $C_{\text {it }}$. Due to the incomplete recording of ownership structure, we must use a smaller sample size to estimate environmental performance once we incorporate these ownership-related regressors.

To explore the effects of ownership structure on corporate environmental performance, we modify the models constructed above to generate the following expanded models:

Model 1B: $\quad(\mathrm{p} / \mathrm{a})_{\mathrm{it}}=\alpha+\gamma(\mathrm{y} / \mathrm{a})_{\mathrm{it}}+\beta\left(\pi_{\mathrm{i}, \mathrm{t}-1} / \mathrm{a}_{\mathrm{it}}\right)+\Psi \mathrm{T}_{\mathrm{it}}+\omega \mathrm{W}_{\mathrm{it}}+\mu \lambda_{\mathrm{it}}+\rho \mathrm{C}_{\mathrm{it}}+\varepsilon_{\mathrm{it}}$,

Model 2B: $\quad[(\mathrm{p} / \mathrm{y}) / \mathrm{a}]_{\mathrm{it}}=\delta+\eta(\mathrm{y} / \mathrm{a})_{\mathrm{it}}+\theta\left(\pi_{\mathrm{i}, \mathrm{t}-1} / \mathrm{a}_{\mathrm{it}}\right)+\kappa \mathrm{T}_{\mathrm{it}}+\sigma \mathrm{W}_{\mathrm{it}}+\tau \lambda_{\mathrm{it}}+\varphi \mathrm{C}_{\mathrm{it}}+\mathrm{v}_{\mathrm{it}}$.

\footnotetext{
${ }^{23}$ Complete estimation results are available upon request.
} 
William Davidson Institute Working Paper 492

The estimation results from these two models are shown in Table 3. Based on the F-test of individual fixed effects, the fixed effects estimator dominates the pooled OLS estimator. Based on the Hausman test of fixed effects, the fixed effects estimator dominates the random effects estimator for Model 1B and the random effects estimator dominates the fixed effects estimator for Model 2B.

For both models, the results indicate that non-dispersed private investors do not affect environmental performance significantly differently than do dispersed investors. In both models, none of the individual effects are statistically significant for the fixed effects estimator. In Model $2 \mathrm{~B}$, none of the individual effects are statistical significant for the random effects estimator. (While two individual effects are statistically significant for the random effects estimator in Model 1B, the Hausman tests rejects the consistency of the random effect estimator in this model.) Thus, this conclusion is robust across the various models and estimators. Moreover, as a collective, these coefficients do not significantly differ from zero. (The log-likelihood ratio $\chi^{2}$ test statistic equals 8.97 and 2.31 for absolute emissions and relative emissions, respectively; given six degrees of freedom, these values are significant only at levels above $10 \%$. $)^{24}$ In contrast to non-dispersed private investors, state ownership significantly lowers absolute emissions relative to dispersed investors based on the fixed effects estimation results. ${ }^{25,26}$

24 For the relative emissions model, the log-likelihood ratio test statistic is based on the random effects estimation results. Based on the fixed effects estimation results, the log-likelihood ratio test statistic equals 7.98; this value is again significant only at levels above $10 \%$.

25 To assess the influence of less than complete reporting of ownership data, we employ residual analysis. In particular, we regress the implied residuals from the fixed effects estimation of Models $1 \mathrm{~A}$ and $2 \mathrm{~A}$ on the RHS ownership structure of Models $1 \mathrm{~B}$ and 2B. The regression results indicate that the sample reduction due to incomplete recording of ownership structure data is not driving the report insignificance of the non-dispersed private ownership effects. (Full regression results are available upon request.)

${ }^{26}$ In several ways, we assess the robustness of these findings of insignificant for the non-dispersed private investor effects. First, we implement a more general logarithmic model. In particular, we regress the $\log$ of emissions on the following factors: $\log$ of fixed assets, $\log$ of production, squared log of production, 


\section{William Davidson Institute Working Paper 492}

Appropriately, we next test the difference between the various non-dispersed private ownership categories and state ownership. Table 4.A displays the test results. In one case, nondispersed private ownership reduces emissions more greatly; in all the other cases, state ownership reduces emissions more greatly. Two differences are significant - (1) state vs. investment fund and (2) state vs. strategic investor - based on the absolute emissions results. State ownership significantly lowers emissions more greatly than does investment fund or strategic investor ownership. All other differences are insignificant. As a collective, the effects of the various nondispersed private ownership types do not differ significantly from the effect of state ownership, based on a joint test of equality, as shown in Table 4.A.

Next, we compare across the non-dispersed private ownership categories, while contrasting concentrated and diffuse ownership structures. Table 4.B.I separately compares strategic investors to investment funds, individual citizens, portfolio companies, and banks. Then Table 4.B.II separately compares foreign investors to investment funds, portfolio companies, individual citizens, strategic investors, and banks. In some cases, concentrated private ownership reduces emissions more greatly; in other cases, diffuse private ownership reduces emissions more greatly. Nevertheless, all of the differences are insignificant, regardless of the model.

These results collectively indicate that the effects of private ownership do not differ across the various types of private ownership. In particular, based on the classification of private categories

product of log of assets and log of production, profit, year indicators, and ownership structure. Second, we define a new category of financial institutions that consists of portfolio companies, investment funds, and banks. Third, we fold domestic non-dispersed private investors into the benchmark category of ownership along with dispersed investors. In other words, state ownership and foreign ownership remain as the only two ownership-type regressors. The overall conclusions are robust to all three modifications. Relative to dispersed ownership, non-dispersed private ownership does not significantly affect environmental performance, while state ownership significantly improves environmental performance. 


\section{William Davidson Institute Working Paper 492}

and based on the distinction involving share dispersion, the effect of more concentrated private ownership does not differ from the effect of diffuse or dispersed private ownership. Perhaps, private ownership in general does not matter. In contrast, state ownership appears to matter.

As noted above, the effects of non-dispersed private investors on environmental performance do not significantly differ from zero as a collective. Therefore, we can properly eliminate these regressors from the estimation. Presumably, this elimination of insignificant regressors improves our estimation of the remaining variables, especially state ownership and ownership concentration based on the single largest shareholder. The resulting estimation results are shown in Table 5. Based on the F-test of fixed effects, the fixed effects estimator dominates the pooled OLS estimator. Based on the Hausman test of fixed effects, the random effects estimator dominates the fixed effects estimator. Thus, we should focus on the random effects estimation results. However, the Hausman test is close to the $10 \%$ critical value in the case of the absolute emissions model. Moreover, in the preceding regressions, the fixed effects estimator always dominates the random effects estimator in the absolute emissions model. Therefore, we also consider the fixed effects estimates of absolute emissions.

The results support the following conclusions. First, the conclusions regarding the effects of financial performance and production are robust to the decrease in sample size. Lagged financial performance begets good current environmental performance. Greater production increases absolute emissions and firms face diseconomies of scale. Second, the significant coefficient associated with the inverse Mills ratio indicates that the Heckman two-step method is needed to correct a selection bias. Third, greater ownership concentration (as measured by the single largest shareholder) leads to better corporate environmental performance. The negative coefficient is significant for the fixed effects estimation of absolute emissions and insignificant for the random effects estimation of both 


\section{William Davidson Institute Working Paper 492}

models. This result contrasts with the results based on the classification of private categories and the distinction involving share dispersion. Perhaps the single largest shareholder provides a better measure of ownership control. This immediate result supports the theoretical notion that monitoring of management is more important than managerial initiative.

Lastly, we examine the effect of state ownership relative to all private ownership types. The final conclusion depends on the treatment of sector-specific effects. The fixed effect estimator controls for industry-specific effects by estimating firm-specific fixed effects. Since industrial classification does not vary over time for an individual firm, any industry-specific effects are subsumed into the firm-specific fixed effects. Based on these fixed effects estimates, greater state ownership leads to better environmental behavior, as indicated by the significantly negative coefficient for both models in Table 5. This result indicates that greater state ownership begets better cost management. Alternatively, it reveals that the state expresses a greater concern for environmental stewardship by reducing emissions more strongly than private investors. Another plausible explanation is that the state privatized firms with relatively modern production and treatment technologies, retaining firms with relatively older technologies. Once new and more stringent environmental laws were passed, the state had to modernize the technologies or risk being shut down.

In contrast to the fixed effects estimator, the between estimator and the random effects estimator do not automatically control for industry-specific effects. When industry indicators are not included as regressors, these two estimators generate results demonstrating that greater state ownership significantly undermines environmental performance, as shown in Table 5. These results collectively indicate that the state owns firms in industries that are more polluting in general. To support this claim, we re-estimate the between group method and random effects method, while 


\section{William Davidson Institute Working Paper 492}

controlling for industry-specific effects by incorporating 22 industry indicator variables. (As shown in Table 6, the industrial indicators are jointly significant in both models for the dominating random effects estimation.) As expected, inclusion of these indicator variables causes the effect of state ownership to become insignificant and reverse sign, as shown in Table 6 . These additional results buttress the claim that state is generally involved in more polluting industries.

These random effects and between group estimation results indicate that the type of ownership does not matter once the analysis controls for sector-specific effects, production levels, and financial performance. This alternative conclusion need not surprise us. Production levels directly affect absolute emissions and indirectly relative emissions due to economies of scale (or diseconomies of scale) associated with the scale of production. Sector-specific effects affect both absolute and relative emissions since the efficacy of treatment technologies and the malleability of production processes varies by sector. Our results support both of these points. Previous studies of ownership effects on financial performance find that certain ownership patterns generate better financial performance. Based on our study, successful financial performance begets good environmental performance, possibly by providing internal finances for investment in pollution reduction projects. The insignificant effects of ownership on environmental performance imply that ownership effects matter only for financial performance. In other words, the ownership effects are incorporated in financial performance. No further ownership effects remain to influence environmental performance. Instead, financial performance serves as the link from better ownership structures to better environmental performance. 
William Davidson Institute Working Paper 492

\section{Summary}

In sum, this paper examines the link from corporate financial performance to corporate environmental performance and explores the effects of ownership structure on environmental performance. Based on analysis of an unbalanced panel of Czech firms in the years 1993 to 1998, successful financial performance improves future environmental performance. Moreover, our analysis finds that increased state ownership actually improves environmental performance relative to all other investor types even though the state apparently retained ownership in more polluting industries. Indeed, during the Czech privatization of the early nineties, the state retained a significant portion of assets in the so-called "strategic" firms, which included many large state-owned enterprises in heavy industry. Heavy industry generally emits above average pollution (World Bank, 1992). Nevertheless, after controlling for firm-specific fixed effects, which capture industry-specific effects, greater state ownership significantly leads to better environmental performance. However, this conclusion depends on the treatment of firm-specific effects. Random effects estimation results indicate that the effect of state ownership on environmental performance is insignificant.

Beyond the effect of state ownership, estimation results in general indicate that no type of private ownership significantly affects environmental performance. Individually and collectively, categories of private investors do not affect environmental performance differently than does the benchmark category of dispersed owners, who hold only a minor share of any single firm.

Overall, the estimation results indicate that the type of owner does not affect environmental performance as long as the analysis controls for production levels, sector-specific effects, and financial performance. In particular, financial performance seems to serve as the link from better ownership structure to improved environmental performance. Put differently, ownership structure does not directly affect environmental performance; it only indirectly affects environmental 
William Davidson Institute Working Paper 492

performance by influencing financial performance.

In contrast, concentrated ownership, as measured by the single largest shareholder, improves the environmental performance, consistent with the notion that concentrated power allows an owner to manage better costs, including environmentally-related costs. 


\section{William Davidson Institute Working Paper 492}

\section{REFERENCES}

Admati, Anat, Paul Pfleiderer, and Josef Zechner (1994): "Large Shareholder Activism, Risk Sharing and Financial Market Equilibrium,” Journal of Political Economy, 102(6), pp. 1097-1130.

Aghion, Philippe and Jean Tirole (1997), "Formal and Real Authority in Organizations," Journal of Political Economy, 105 (1), pp. 1-27.

Anderson, T. W. and Cheng Hsiao (1981), “Estimation of Dynamic Models with Error Components,” Journal of the American Statistical Association, 76(3), pp. 598-606.

Anderson, T. W. and Cheng Hsiao (1982), "Formulation and Estimation of Dynamic Models using Panel Data," Journal of Econometrics, 18 (1), pp.47-82.

Arellano Manuel and Stephen Bond (1991), "Some Test for Specification for Panel Data: Monte Carlo Evidence and an Application to Employment Equations," Review of Economic Studies, 58(2), pp. 277-297.

Austin, David, Alberini, Anna, and Videras, Julio (1999), “Is There a Link between a Firm’s Environmental and Financial Performance?” presented at NBER Summer Institute Public Economics Workshop: Public Policy and the Environment, Cambridge, MA, August 2, 1999.

Bolton, Patrick and Ernst von Thadden (1998), "Blocks, Liquidity, and Corporate Control," Journal of Finance, 53(1), pp. 1-25.

Bosch, Jean, E. Eckard Woodrow, and Insup Lee (1998), “EPA Enforcement, Firm Response Strategies, and Stockholder Wealth: An Empirical Examination," Managerial and Decision Economics, 19(3), pp. 167-177.

Bun, Maurice and Jan Kiviet (1999), "On the Small Sample Accuracy of Various Inference Procedures in Dynamic Panel Data Models," Working Paper, University of Amsterdam.

Claessens, Stijn and Simeon Djankov (1999), “Ownership Concentration and Corporate Performance in the Czech Republic,” Journal of Comparative Economics, 27(3), pp. 498-513. 


\section{William Davidson Institute Working Paper 492}

Czech Ministry of Environment (1998), Statistical Environmental Yearbook of the Czech Republic, Prague: Czech Ministry of the Environment.

Djankov, Simeon (1999), “Ownership Structure and Enterprise Restructuring in Six Newly Independent States," Comparative Economic Studies, 41(1), pp. 75-95.

Earnhart, Dietrich (1997), "Enforcement of Environmental Protection Laws under Communism and Democracy," Journal of Law and Economics, 40(2), pp. 377-402.

Earnhart, Dietrich (2000a), "Optimal Mix of Penalties in a Principal-Agent Model under Different Institutional Arrangements," Review of Economics and Statistics, 82(4), pp. 634-645.

Earnhart, Dietrich (2000b), "Environmental Crime and Punishment in the Czech Republic: Penalties Against Firms and Employees," J. of Comparative Economics, 28, pp. 379-399.

Earnhart, Dietrich (2000c), "Liability for Past Environmental Contamination and Privatization”, William Davidson Institute working paper \# 302 (March, 2000).

Frydman, Roman, Cheryl Gray, Marek Hessel, and Andrzej Rapaczynski (1999), "When Does Privatization Work? The Impact of Private Ownership on Corporate Performance in the Transition Economies," Quarterly Journal of Economics, 114(4), pp. 1153-1191.

Furubotn, Erik and Svetozar Pejovich (1972), "Property Rights and Economic Theory: A Survey of Recent Literature," Journal of Economic Literature, 10(4), pp. 1137-1162.

Gottsman, Laura and Jon Kessler (1998), "Smart Screened Investments: Environmentally-Screened Equity Funds that Perform Like Conventional Funds," Journal of Investing, 7(4) pp. 1-10.

Gupta, Nandini, John Ham, and Jan Svejnar (2000), "Priorities and Sequencing in Privatization: Theory and Evidence from the Czech Republic,” William Davidson Institute Working Paper No. 369.

Hart, Oliver and John Moore (1990), "Property Rights and the Nature of the Firm," Journal of Political Economy, 98(6), pp. 1119-1158. 
William Davidson Institute Working Paper 492

Harris, Mark and Laszlo Matyas (1996), “A Comparative Analysis of Different Estimator for Dynamic Panel Data Models," Monash University, Department of Econometrics and Business Statistics working paper No. 4/96, Australia.

Heckman, James (1979), “Sample Selection Bias as Specification Error,” Econometrica, 47, pp. 153-161.

Judson, Ruth and Ann Owen (1999), "Estimating Dynamic Panel Data Models: A Guide for Macroeconomists," Economic Letters, 65(1), pp. 9-15.

Keane, Michael and David Runkle (1992), “On the Estimation of Panel-Data Models with Serial Correlation When Instruments Are Not Strictly Exogenous," Journal of Business and Economic Statistics, 10(1), pp. 1-9.

Kiviet, Jan F. (1995), “On Bias, Inconsistency, and Efficiency of Various Estimators in Dynamic Panel Data Models," Journal of Econometrics, 68(1), pp. 53-78.

Klassen, Robert and Curtis McLaughlin (1996), “The Impact of Environmental Management on Firm Performance," Management Science, 42(8), pp. 1199-1214.

Kocenda, Evzen (1999): “Residual State Property in the Czech Republic,” Eastern Economic Review, 37(5), pp. 6-35.

Kocenda, Evzen and Jan Svejnar (2002), "The Effects of Ownership Forms and Concentration on Firm Performance after Large-Scale Privatization,” William Davidson Institute working paper No. 471, May.

Konar, Shameek and Mark Cohen (2002), “Does the Market Value Environmental Performance?” Review of Economics and Statistics, 83(2), pp. 281-289.

Kotrba, Josef (1995) “Privatization Process in the Czech Republic: Players and Winners.” In Svejnar, J., The Czech Republic and Economic Transition in Eastern Europe. San Diego, London and Toronto: Harcourt Brace, Academic Press, 1995, p. 159-198. 
William Davidson Institute Working Paper 492

Kotrba, Josef (1997), “The Demise of Employee Ownership in the Czech Privatization Programme?” In Uvalic, M., Whitehead, D. (eds.), Privatization Surprises in Transition Economies: Employee-ownership in Central and Eastern Europe. Cheltenham, U.K: N.H Elgar American International Distribution Corporation, 1997, pp. 120-35.

Lízal, Lubomír and Jan Svejnar (2002a), "Investment, Credit Rationing, and the Soft Budget Constraint: Evidence from Czech Panel Data," Review of Economics and Statistics, 83(2), pp. 353-370.

Lízal, Lubomír and Jan Svejnar (2002b), "Financial Conditions and Investment during the Transition: Evidence from Czech Firms," Chapter 11 in Anna Meyendorff and Anjan Thakor, editors: Designing Financial Systems in Transition Economies: Strategies for Reform in Central and Eastern Europe, MIT Press, Cambridge, MA, 2002, pp. 215-260.

Magat, Wesley and Kip Viscusi (1990), “Effectiveness of the EPA’s Regulatory Enforcement: The Case of Industrial Effluent Standards," Journal of Law and Economics, 33(2), pp. 331-360.

Megginson, William and Jeffry Netter (2001), "From State to Market: A Survey of Empirical Studies on Privatization," Journal of Economic Literature, 39(2), pp. 321-389.

Nerlove, Marc (1967) “Experimental Evidence on the Estimation of Dynamic Economic Relations in a Time Series of Cross-Sections," Economic Studies Quarterly, 18, pp. 42-74.

Nickell, Stephen (1981) “Biases in Dynamic Models with Fixed Effects,” Econometrica, 49(6), pp. 1417-26. Shleifer, Andrei and Robert Vishny (1997), “A Survey of Corporate Governance,” Journal of Finance, 52(2), pp. 737-783.

Weiss, Andrew and Georgiy Nikitin (2002), "Effects of Ownership by Investment Funds on The Performance of Czech Firms," Chapter 10 in Anna Meyendorff and Anjan Thakor, editors: Designing Financial Systems in Transition Economies: Strategies for Reform in Central and Eastern Europe, MIT Press, Cambridge, MA, 2002, pp. 187-214.

World Bank (1992), “Czech and Slovak Federal Republic Joint Environmental Study,” Report No. 9623-CS. 
William Davidson Institute Working Paper 492

World Bank (1999), Country Economic Memorandum - Czech Republic, report prepared by Julia Bucknall, Rita Cestiti, and Gordon Hughes; World Bank: Washington, DC. 
William Davidson Institute Working Paper 492

Figure 1

$\begin{array}{rrrrrc}\text { Year } & \text { SO2 } & \text { NOx } & \text { CO } & \text { PM } & \begin{array}{c}\text { Production of } \\ \text { Electricity }\end{array} \\ 1980 & 2148 & 731 & 894 & 1267 & 53 \\ 1985 & 2161 & 795 & 899 & 1015 & 58 \\ 1990 & 1876 & 742 & 891 & 631 & 63 \\ 1991 & 1776 & 725 & 1101 & 592 & 61 \\ 1992 & 1538 & 698 & 1045 & 501 & 59 \\ 1993 & 1419 & 574 & 967 & 441 & 59 \\ 1994 & 1278 & 434 & 1026 & 355 & 59 \\ 1995 & 1091 & 412 & 874 & 201 & 61 \\ 1996 & 946 & 432 & 886 & 179 & 64 \\ 1997 & 700 & 423 & 877 & 128 & 65 \\ 1998 & 443 & 413 & 767 & 86 & 65 \\ 1999 & 269 & 390 & 686 & 67 & 65 \\ 2000 & 266 & 400 & 650 & 56 & 73\end{array}$

Figure 1: Air Emissions in Czech Republic

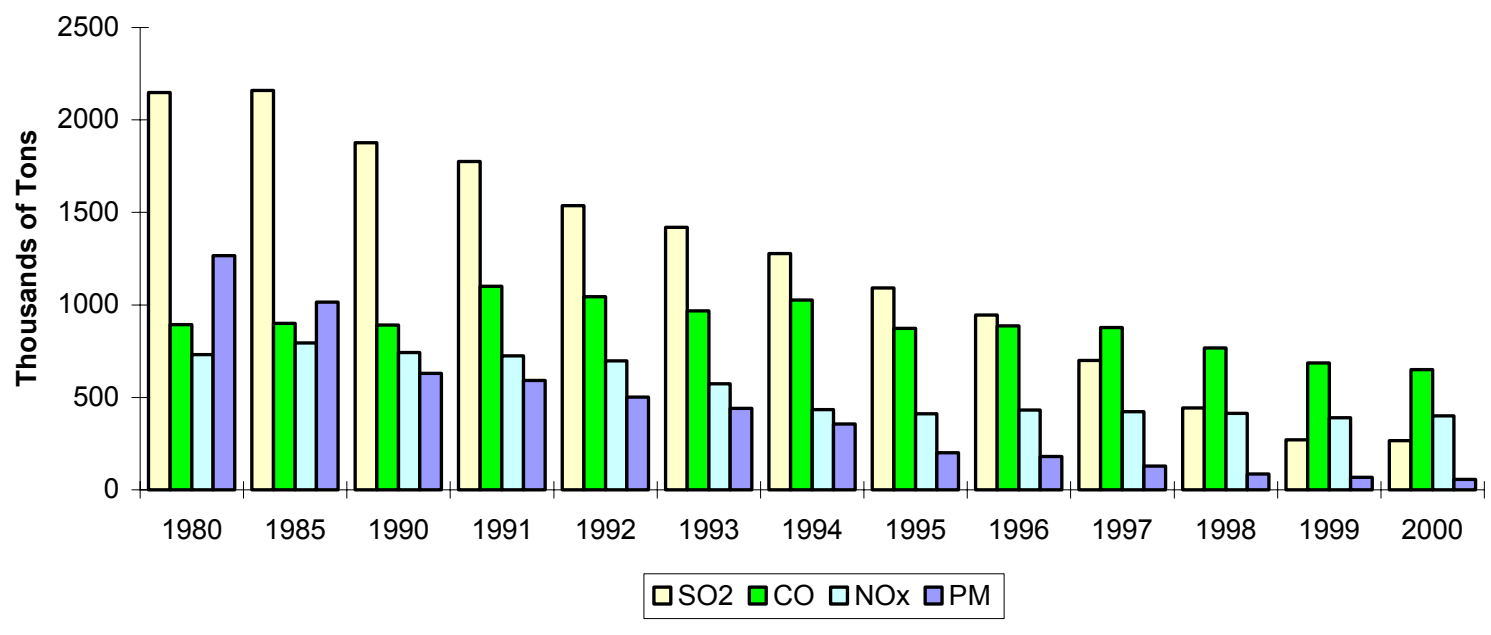

Source: Ročenka životního prostředí, various issues. 
William Davidson Institute Working Paper 492

TABle 1A. Year Distribution OF DAta for BASIC Regressions

\begin{tabular}{lccc}
\hline \hline Year & & Freq. & Percent \\
\hline & 1993 & 353 & 13.43 \\
& 1994 & 467 & 17.77 \\
& 1995 & 468 & 17.81 \\
& 1996 & 484 & 18.42 \\
& 1997 & 457 & 17.39 \\
& 1998 & 399 & 15.18 \\
\hline Total & & 2628 & 100 \\
\hline
\end{tabular}

Notes:

For year 1999 we do not have data on emissions.

Year 1993 is used for lagged values.

Ownership data cover mostly the years 1996 to 1999. 


\section{TABLe 1.B}

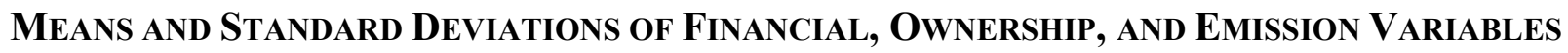

\begin{tabular}{lcrr}
\hline \multicolumn{1}{c}{ Variable } & \# of Obs & Mean & Std. Deviation \\
\hline Fixed Assets (000s CZK) & 2,628 & 886,875 & $2,193,577$ \\
Profit (000s CZK) & 2,625 & -179 & 236,383 \\
Production Value (000s CZK) & 2,628 & $1,222,220$ & $3,559,092$ \\
Emissions Total (tons) & 2,628 & 963 & 4063 \\
Emissions of Carbon Monoxide [CO] (tons) & 2,628 & 127 & 1189 \\
Emissions of Sulfur Dioxide [SO ${ }_{2}$ (tons) & 2,628 & 515 & 2440 \\
Emissions of Particulate Matter [PM] (tons) & 2,628 & 121 & 621 \\
Emissions of Nitrous Oxides [NO ${ }^{\text {] }}$ (tons) & 2,628 & 200 & 849 \\
State Ownership share (\%) & 1,168 & 6.14 & 16.65 \\
Strategic Investor Ownership share (\%) & 1,168 & 27.77 & 30.41 \\
Individual Citizens Ownership share (\%) & 1,168 & 5.72 & 16.88 \\
Bank Ownership share (\%) & 1,168 & 0.99 & 5.70 \\
Portfolio Company Ownership share (\%) & 1,168 & 2.17 & 9.02 \\
Investment Funds Ownership share (\%) & 1,168 & 12.80 & 20.12 \\
Foreign Ownership share (\%) & 1,168 & 7.61 & 22.64 \\
Concentration: Single Largest Shareholder (\%) & 1,168 & 45.34 & \\
\hline
\end{tabular}

Note: $\mathrm{CZK}=$ Czech Crowns 
William Davidson Institute Working Paper 492

Table 1.C. Distribution AcCording To Industrial Classification

\begin{tabular}{|c|c|c|}
\hline Industry & Obs. & Percent \\
\hline Agriculture, Hunting, Forestry, Fisheries & 20 & 0.76 \\
\hline Mining and Quarrying & 33 & 1.26 \\
\hline Manufacturing of Food Products, Beverages, and Tobacco & 397 & 15.11 \\
\hline Manufacturing of Textiles, Textile Products, Leather, and Leather Products & 216 & 8.22 \\
\hline $\begin{array}{l}\text { Manufacturing of Wood, Wood Products, Pulp, Paper, and Paper Products } \\
\text { and Publishing and Printing }\end{array}$ & 89 & 3.39 \\
\hline Manufacturing of Coke and Refined Petroleum & 14 & 0.53 \\
\hline Manufacturing of Chemicals, Chemical Products, and Synthetic Fibers & 126 & 4.79 \\
\hline Manufacturing of Rubber and Plastic Products & 53 & 2.02 \\
\hline Manufacturing of Other Non-Metallic Mineral Products & 234 & 8.9 \\
\hline Manufacturing of Basic Metals and Fabricated Metal Products & 308 & 11.72 \\
\hline Manufacturing of Machinery and Equipment n.e.c. & 301 & 11.45 \\
\hline Manufacturing of Electrical and Optical Equipment & 117 & 4.45 \\
\hline Manufacturing of Transport Equipment & 193 & 7.34 \\
\hline Manufacturing n.e.c. & 92 & 3.5 \\
\hline Electricity, Gas, and Water Supply & 160 & 6.09 \\
\hline Construction & 120 & 4.57 \\
\hline Wholesale and Retail Trade and Repair of Motor Vehicles & 11 & 0.42 \\
\hline Hotels and Restaurants & 16 & 0.61 \\
\hline Transport, Postal Service, Storage, and Telecommunications & 6 & 0.23 \\
\hline Finance, Real Estate, Rentals, Business, Research, Public Administration & 72 & 2.74 \\
\hline Education, Health, and Veterinary Services & 22 & 0.84 \\
\hline Other Public and Social Services & 11 & 0.42 \\
\hline Other n.e.c & 17 & 0.65 \\
\hline Total & 2628 & 100 \\
\hline
\end{tabular}


William Davidson Institute Working Paper 492

TABLE 1.D. OWNERShIP SHARES BY INDUSTRIAL Classification

\begin{tabular}{|c|c|c|c|c|c|c|c|c|}
\hline \multirow[b]{2}{*}{ Industry } & \multirow[b]{2}{*}{$\mathrm{N}$} & \multicolumn{6}{|c|}{ Owner } & \multirow[b]{2}{*}{ Foreign } \\
\hline & & State & Strategic & Citizen & Bank & Portfolio & Fund & \\
\hline Agriculture, Forestry, Fisheries & 10 & 11.3 & 20.9 & 7.7 & 0.0 & 4.6 & 12.1 & 0.0 \\
\hline Mining and Quarrying & 14 & 27.5 & 13.3 & 0.8 & 0.0 & 10.0 & 19.4 & 0.0 \\
\hline Food, Beverages, and Tobacco & 185 & 7.3 & 30.9 & 5.3 & 1.0 & 1.7 & 7.3 & 10.4 \\
\hline Mfg. of Textiles and Leather & 93 & 2.6 & 29.7 & 5.1 & 0.4 & 2.8 & 19.4 & 1.0 \\
\hline Wood, Pulp, Paper, and Publishing & 40 & 4.1 & 31.2 & 2.6 & 3.6 & 0.8 & 24.3 & 6.7 \\
\hline Mfg. of Coke and Petroleum & 4 & 53.2 & 0.0 & 0.0 & 3.5 & 0.0 & 1.5 & 0.0 \\
\hline Mfg. of Chemicals & 50 & 15.2 & 30.5 & 2.7 & 1.4 & 0.0 & 11.9 & 3.4 \\
\hline Mfg. of Rubber and Plastic & 21 & 0 & 24.1 & 4.9 & 0.5 & 9.9 & 18.4 & 7.6 \\
\hline Mfg. of Non-Metallic Minerals & 89 & 2.4 & 18.2 & 6.0 & 1.0 & 0.9 & 10.8 & 23.4 \\
\hline Mfg. of Basic Metals & 155 & 5.1 & 28.7 & 7.8 & 0.1 & 3.2 & 10.4 & 8.6 \\
\hline Mfg. of Machinery n.e.c. & 154 & 1.4 & 26.5 & 3.0 & 2.3 & 1.7 & 19.6 & 4.8 \\
\hline Mfg. of Electrical and Optical & 48 & 1.1 & 24.3 & 8.8 & 0.4 & 2.8 & 15.1 & 5.2 \\
\hline Mfg. of Transport Equipment & 82 & 2.7 & 34.3 & 8.9 & 0.5 & 0.7 & 9.6 & 4.6 \\
\hline Mfg. n.e.c. & 35 & 4 & 23.1 & 4.2 & 0.0 & 4.7 & 11.3 & 4.2 \\
\hline Electricity, Gas, and Water Supply & 59 & 25.8 & 22.2 & 0.0 & 1.1 & 1.9 & 13.7 & 7.2 \\
\hline Construction & 56 & 0.7 & 31.3 & 8.3 & 1.5 & 1.9 & 9.0 & 14.1 \\
\hline Trade \& Repair of Motor Vehicles & 4 & 0 & 33.5 & 0.0 & 0.0 & 0.0 & 10.0 & 8.9 \\
\hline Hotels and Restaurants & 9 & 1.7 & 18.8 & 9.6 & 0.0 & 1.1 & 28.6 & 0.0 \\
\hline Transport, Postal, Telecoms & 1 & 100 & 0.0 & 0.0 & 0.0 & 0.0 & 0.0 & 0.0 \\
\hline Finance, Business, Public Admin. & 35 & 9.4 & 40.6 & 12.6 & 0.0 & 1.1 & 3.9 & 0.0 \\
\hline Education, Health, and Veterinary & 12 & 4.4 & 19.4 & 12.4 & 2.4 & 5.6 & 13.3 & 0.0 \\
\hline Other Public and Social Services & 5 & 12.4 & 8.6 & 19.5 & 0.0 & 0.0 & 0.0 & 19.8 \\
\hline Other n.e.c & 7 & 26.3 & 39.6 & 7.6 & 0.0 & 0.0 & 5.9 & 0.0 \\
\hline
\end{tabular}


William Davidson Institute Working Paper 492

Table 2. Estimation of Environmental Performance: Effect of Financial Performance

\begin{tabular}{|c|c|c|}
\hline RHS Variable & Model 1A:Absolute Emissions & Model 2A:Relative Emissions \\
\hline \multicolumn{3}{|l|}{ Pooled OLS } \\
\hline Production / Fixed Assets & $\begin{array}{c}0.262 * * * \\
(0.057)\end{array}$ & $\begin{array}{c}1.426 * * * \\
(0.448)\end{array}$ \\
\hline Lagged Profit / Fixed Assets & $\begin{array}{l}-0.266 \\
(0.533)\end{array}$ & $\begin{array}{l}-13.261 \\
(10.381)\end{array}$ \\
\hline Adjusted $\mathrm{R}^{2}$ & 0.105 & 0.056 \\
\hline $\begin{array}{l}\text { LM Heteroskedasticity Test } \\
\text { [significance level] }\end{array}$ & $\begin{array}{c}9.24 * * * \\
{[0.002]}\end{array}$ & $\begin{array}{l}4.95 * * \\
{[0.027]}\end{array}$ \\
\hline \multicolumn{3}{|l|}{ Between Group } \\
\hline Production / Fixed Assets & $\begin{array}{c}0.300 * * * \\
(0.026)\end{array}$ & $\begin{array}{c}2.122 * * * \\
(0.379)\end{array}$ \\
\hline Lagged Profit / Fixed Assets & $\begin{array}{l}-1.663 * * * \\
(0.491)\end{array}$ & $\begin{array}{l}-69.341 * * * \\
(7.034)\end{array}$ \\
\hline Adjusted $\mathrm{R}^{2}$ & 0.205 & 0.2 \\
\hline $\begin{array}{l}\text { LM Heteroskedasticity Test } \\
\text { [significance level] }\end{array}$ & $\begin{array}{l}4.79 * * \\
{[0.028]}\end{array}$ & $\begin{array}{c}272 * * * \\
{[0.000]}\end{array}$ \\
\hline \multicolumn{3}{|l|}{ Fixed Effects } \\
\hline Production / Fixed Assets & $\begin{array}{c}0.336 * * * \\
(0.053)\end{array}$ & $\begin{array}{c}0.832 * * * \\
(0.299)\end{array}$ \\
\hline Lagged Profit / Fixed Assets & $\begin{array}{l}-0.391 \\
(0.306)\end{array}$ & $\begin{array}{l}-3.199 * * \\
(1.273)\end{array}$ \\
\hline Adjusted $\mathrm{R}^{2}$ & 0.72 & 0.759 \\
\hline $\begin{array}{l}\text { LM Heteroskedasticity Test } \\
\text { [significance level] }\end{array}$ & $\begin{array}{l}243 * * * \\
{[0.000]}\end{array}$ & $\begin{array}{c}0.798 \\
{[0.372]}\end{array}$ \\
\hline \multicolumn{3}{|l|}{ Random Effects } \\
\hline Production / Fixed Assets & $\begin{array}{c}0.313 * * * \\
(0.019)\end{array}$ & $\begin{array}{c}1.193 * * * \\
(0.163)\end{array}$ \\
\hline Lagged Profit / Fixed Assets & $\begin{aligned}- & 0.506 * * * \\
& (0.154)\end{aligned}$ & $\begin{array}{l}-7.453 * * * \\
\quad(1.274)\end{array}$ \\
\hline Adjusted $\mathrm{R}^{2}$ & 0.105 & 0.052 \\
\hline $\begin{array}{l}\text { LM Heteroskedasticity Test } \\
\text { [significance level] }\end{array}$ & $\begin{array}{c}1.290 \\
{[0.256]}\end{array}$ & $\begin{array}{c}3.11 * \\
{[0.078]}\end{array}$ \\
\hline $\begin{array}{l}\text { F-test of Individual Effects } \\
\text { [significance level] }\end{array}$ & $\begin{array}{c}9.43 * * * \\
{[0.000]}\end{array}$ & $\begin{array}{c}12.78 * * * \\
{[0.000]}\end{array}$ \\
\hline $\begin{array}{l}\text { Hausman Fixed vs. Random } \\
\text { [significance level ] }\end{array}$ & $\begin{array}{c}0.843 \\
{[0.839]}\end{array}$ & $\begin{array}{l}7.597 * * \\
{[0.022]}\end{array}$ \\
\hline No. of Firms / No. of Observations & $564 / 2173$ & $564 / 2173$ \\
\hline
\end{tabular}

Standard errors are noted inside parentheses; $p$-values are noted inside square brackets.

$*, * *$, and $* * *$ indicate statistical significance at $0.10,0.05$, and 0.01 levels, respectively.

Each regression additionally includes an intercept term and year indicators. 
Table 3. Estimation of EnVironmental Performance: EfFects of OWNership

\begin{tabular}{|c|c|c|c|c|c|c|c|c|}
\hline \multirow{2}{*}{ RHS Variable } & \multicolumn{4}{|c|}{ Model 1B Absolute Emissions } & \multicolumn{4}{|c|}{ Model 2B Relative Emissions } \\
\hline & OLS & Between & Fixed Ef. & Random Ef. & OLS & Between & Fixed Ef. & Random Ef. \\
\hline Production / Assets & $\begin{array}{c}0.2661 * * * \\
(0.0412)\end{array}$ & $\begin{array}{c}0.3295 * * * \\
(0.0187)\end{array}$ & $\begin{array}{c}0.4905 * * * \\
(0.1545)\end{array}$ & $\begin{array}{c}0.2950 * * * \\
(0.0168)\end{array}$ & $\begin{array}{c}1.5278 \\
(0.3507)\end{array}$ & $\begin{array}{c}2.0588 * * * \\
(0.3454)\end{array}$ & $\begin{array}{c}0.9762 * * \\
(0.3999)\end{array}$ & $\begin{array}{c}1.2752 * * * \\
(0.1403)\end{array}$ \\
\hline Lagged Profits / Assets & $\begin{array}{l}-0.8288 \\
(0.6294)\end{array}$ & $\begin{array}{c}-1.4458 * * * \\
(0.3367)\end{array}$ & $\begin{array}{c}-0.7064 * \\
(0.4236)\end{array}$ & $\begin{array}{c}-0.9214 * * * \\
(0.1531)\end{array}$ & $\begin{array}{c}-17.9624 \\
(14.5202)\end{array}$ & $\begin{array}{c}-52.7879 * * * \\
(6.2180)\end{array}$ & $\begin{array}{c}-3.3384 * * \\
(1.6365)\end{array}$ & $\begin{array}{c}-4.3274 * * * \\
(0.6791)\end{array}$ \\
\hline State Ownership (\%) & $\begin{array}{l}0.0083^{*} \\
(0.0045)\end{array}$ & $0.0128 *$ & $\begin{array}{c}-0.0079 * * \\
(0.0037)\end{array}$ & $\begin{array}{c}0.0006 \\
(0.0037)\end{array}$ & $\begin{array}{l}-0.0316 \\
(0.0310)\end{array}$ & $\begin{array}{l}-0.0205 \\
(0.1132)\end{array}$ & $\begin{array}{l}-0.0138 \\
(0.0115)\end{array}$ & $\begin{array}{l}-0.0177 \\
(0.0177)\end{array}$ \\
\hline Investment Fund Ownership (\%) & $\begin{array}{c}-0.0008 \\
(0.0024)\end{array}$ & $\begin{array}{c}0.0000 \\
(0.0053)\end{array}$ & $\begin{array}{c}-0.0001 \\
(0.0024)\end{array}$ & $\begin{array}{l}-0.0006 \\
(0.0029)\end{array}$ & $\begin{array}{c}-0.0267 \\
(0.0206)\end{array}$ & $\begin{array}{l}-0.0393 \\
(0.0983)\end{array}$ & $\begin{array}{l}-0.0025 \\
(0.0102)\end{array}$ & $\begin{array}{c}-0.0038 \\
(0.0132)\end{array}$ \\
\hline Bank Ownership (\%) & $\begin{array}{l}-0.0047 \\
(0.0054)\end{array}$ & $\begin{array}{l}-0.0035 \\
(0.0154)\end{array}$ & $\begin{array}{l}-0.0057 \\
(0.0046)\end{array}$ & $\begin{array}{l}-0.0044 \\
(0.0064)\end{array}$ & $\begin{array}{l}-0.0420 \\
(0.0246)\end{array}$ & $\begin{array}{l}0.0567^{*} \\
(0.2836)\end{array}$ & $\begin{array}{l}-0.0221 \\
(0.0140)\end{array}$ & $\begin{array}{l}-0.0263 \\
(0.0273)\end{array}$ \\
\hline Portfolio Company Ownership (\%) & $\begin{array}{c}0.0054 \\
(0.0069)\end{array}$ & $\begin{array}{c}0.0139 \\
(0.0095)\end{array}$ & $\begin{array}{l}-0.0059 \\
(0.0051)\end{array}$ & $\begin{array}{l}-0.0016 \\
(0.0048)\end{array}$ & $\begin{array}{c}0.0795 \\
(0.0933)\end{array}$ & $\begin{array}{c}0.2667 \\
(0.1758)\end{array}$ & $\begin{array}{l}-0.0055 \\
(0.0148)\end{array}$ & $\begin{array}{c}0.0020 \\
(0.0211)\end{array}$ \\
\hline Citizen Ownership (\%) & $\begin{array}{c}-0.0108 * * \\
(0.0047)\end{array}$ & $\begin{array}{c}-0.0060 \\
(0.0058)\end{array}$ & $\begin{array}{l}-0.0052 \\
(0.0039)\end{array}$ & $\begin{array}{c}-0.0095 * * * \\
(0.0036)\end{array}$ & $\begin{array}{c}0.0299 \\
(0.0871)\end{array}$ & $\begin{array}{c}0.1635 \\
(0.1066)\end{array}$ & $\begin{array}{l}-0.0113 \\
(0.0135)\end{array}$ & $\begin{array}{l}-0.0017 \\
(0.0177)\end{array}$ \\
\hline Strategic Investor Ownership (\%) & $\begin{array}{c}-0.0034 \\
(0.0031)\end{array}$ & $\begin{array}{c}-0.0024 \\
(0.0053)\end{array}$ & $\begin{array}{l}-0.0036 \\
(0.0040)\end{array}$ & $\begin{array}{l}-0.0046 \\
(0.0029)\end{array}$ & $\begin{array}{l}-0.0519 \\
(0.0229)\end{array}$ & $\begin{array}{c}-0.0958^{* *} \\
(0.0986)\end{array}$ & $\begin{array}{l}-0.0003 \\
(0.0118)\end{array}$ & $\begin{array}{l}-0.0022 \\
(0.0132)\end{array}$ \\
\hline Foreign Investor Ownership (\%) & $\begin{array}{l}-0.0058 \\
(0.0037)\end{array}$ & $\begin{array}{l}-0.0035 \\
(0.0061)\end{array}$ & $\begin{array}{l}-0.0041 \\
(0.0040)\end{array}$ & $\begin{array}{c}-0.0069 * \\
(0.0036)\end{array}$ & $\begin{array}{l}-0.0361 \\
(0.0178)\end{array}$ & $\begin{array}{c}-0.0082 * * \\
(0.1118)\end{array}$ & $\begin{array}{l}-0.0017 \\
(0.0136)\end{array}$ & $\begin{array}{l}-0.0037 \\
(0.0172)\end{array}$ \\
\hline Concentration: Largest Shareholder & $\begin{array}{c}0.0046 \\
(0.0035)\end{array}$ & $\begin{array}{c}0.0051 \\
(0.0051)\end{array}$ & $\begin{array}{l}-0.0017 \\
(0.0036)\end{array}$ & $\begin{array}{c}0.0023 \\
(0.0029)\end{array}$ & $\begin{array}{c}0.0406 \\
(0.0361)\end{array}$ & $\begin{array}{c}0.1002 \\
(0.0943)\end{array}$ & $\begin{array}{l}-0.0021 \\
(0.0124)\end{array}$ & $\begin{array}{l}-0.0015 \\
(0.0137)\end{array}$ \\
\hline Inverse Mills Ratio & $\begin{array}{c}0.6042 * * * \\
(0.1229) \\
\end{array}$ & $\begin{array}{c}0.4582 * * * \\
(0.1565)\end{array}$ & $\begin{array}{l}1.1599 * * \\
(0.4633) \\
\end{array}$ & $\begin{array}{c}0.6665 * * * \\
(0.1364)\end{array}$ & $\begin{array}{c}6.9877 * * * \\
(1.5024) \\
\end{array}$ & $\begin{array}{c}4.7923 * * * \\
(2.8903) \\
\end{array}$ & $\begin{array}{l}8.3311 * * \\
(4.1570) \\
\end{array}$ & $\begin{array}{c}9.7183 * * * \\
(1.1030) \\
\end{array}$ \\
\hline Adjusted $\mathrm{R}^{2}$ & 0.304 & 0.52 & 0.785 & 0.295 & 0.139 & 0.226 & 0.973 & 0.092 \\
\hline $\begin{array}{l}\text { LM Heteroskedasticity Test } \\
\text { [significance level] }\end{array}$ & $\begin{array}{c}10.58 * * * \\
{[0.001]}\end{array}$ & $\begin{array}{c}0.557 \\
{[0.456]} \\
\end{array}$ & $\begin{array}{c}73.63 * * * \\
{[0.000]} \\
\end{array}$ & $\begin{array}{c}3.30 * \\
{[0.069]}\end{array}$ & $\begin{array}{c}9.350 * * * \\
{[0.002]}\end{array}$ & $\begin{array}{c}66.49 * * * \\
{[0.000]}\end{array}$ & $\begin{array}{c}0.202 \\
{[0.964]} \\
\end{array}$ & $\begin{array}{c}0.786 \\
{[0.375]} \\
\end{array}$ \\
\hline $\begin{array}{l}\text { F-test of Individual Effects } \\
\text { [significance level] }\end{array}$ & \multicolumn{4}{|c|}{$6.39 * * *$} & \multicolumn{4}{|c|}{$76.94 * * *$} \\
\hline $\begin{array}{l}\text { Hausman Fixed vs. Random } \\
\text { [significance level] }\end{array}$ & \multicolumn{4}{|c|}{$17.85 * * *$} & \multicolumn{4}{|c|}{2.270} \\
\hline Joint Test of Ownership Significance & \multicolumn{4}{|c|}{8.966} & \multicolumn{4}{|c|}{2.311} \\
\hline $\mathrm{X}^{2}(7)$ [significance level] & \multicolumn{4}{|c|}{$[0.255]$} & \multicolumn{4}{|c|}{$[0.940]$} \\
\hline No. of Firms / No. of Observations & \multicolumn{4}{|c|}{$463 / 1127$} & \multicolumn{4}{|c|}{$463 / 1127$} \\
\hline
\end{tabular}

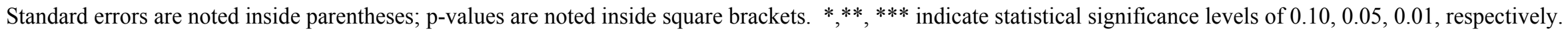
Each regression also includes an intercept term and year indicators. 
TABle 4. COMPARISON OF OWNERSHIP TYPES

Table 4.A. Various Types Of Private OWnership Versus State OWNership

\begin{tabular}{lccc}
\hline \hline & \multicolumn{1}{l}{$\begin{array}{l}\text { Coefficient } \\
\text { Difference }\end{array}$} & Standard Error & P-value \\
\hline Private Ownership Category & 0.0078 & 0.0031 & 0.012 \\
\hline Investment Funds & 0.0027 & 0.0028 & 0.338 \\
Individual Citizens & 0.0019 & 0.0043 & 0.659 \\
Portfolio Companies & 0.0022 & 0.0041 & 0.600 \\
Bank & 0.0042 & 0.0022 & 0.059 \\
Strategic Investors & 0.0037 & 0.0028 & 0.187 \\
Foreign Investors & 8.317 & & 0.216 \\
Joint Test $\chi^{2}(6)$ & 0.0138 & 0.0166 & \\
\hline Based on Relative Emissions (Random Effect Estimates) & & 0.403 \\
\hline Investment Funds & 0.0160 & 0.0192 & 0.406 \\
Individual Citizens & 0.0197 & 0.0232 & 0.397 \\
Portfolio Companies & -0.0087 & 0.0281 & 0.785 \\
Bank & 0.0155 & 0.0140 & 0.268 \\
Strategic Investors & 0.014 & 0.0179 & 0.436 \\
Foreign Investors & 2.143 & & 0.906 \\
\hline Joint Test $\chi^{2}(6)$ & & &
\end{tabular}


TABle 4.B.I. Diffuse Private OWNERShiP VS. STRATEgic INVESTOR

\begin{tabular}{lccc}
\hline \hline Diffuse Ownership Category & Coefficient Difference & Standard Error & P-value \\
\hline Based on Absolute Emissions (Fixed Effect Estimates) & & \\
\hline Investment Funds & 0.0035 & 0.0033 & 0.280 \\
Individual Citizens & -0.0016 & 0.0025 & 0.528 \\
Portfolio Companies & -0.0023 & 0.0042 & 0.589 \\
Bank & -0.0021 & 0.0045 & 0.647 \\
\hline Based on Relative Emissions (Random Effect Estimates) & & \\
\hline Investment Funds & -0.0016 & 0.0109 & 0.883 \\
Individual Citizens & 0.0005 & 0.0148 & 0.972 \\
Portfolio Companies & 0.0042 & 0.0188 & 0.822 \\
Bank & -0.0241 & 0.0254 & 0.342 \\
\hline
\end{tabular}


Table 4.b.II. Private OWnership Vs. Foreign InVestor

\begin{tabular}{lrcr}
\hline \hline Diffuse Ownership Category & Coefficient Difference & Standard Error & P-value \\
\hline \multicolumn{1}{l}{ Based on Absolute Emissions (Fixed Effect Estimates) } & & \\
\hline Investment Funds & 0.0040 & 0.0033 & 0.225 \\
Individual Citizens & -0.0010 & 0.0028 & 0.703 \\
Portfolio Companies & -0.0018 & 0.0045 & 0.690 \\
Strategic & 0.0005 & 0.0018 & 0.781 \\
Bank & -0.0015 & 0.0044 & 0.724 \\
Joint Test $\chi^{2}(5)$ & 3.199 & & 0.669 \\
Based on Relative Emissions (Random Effect Estimates) & & \\
\hline Investment Funds & -0.0001 & 0.0154 & 0.993 \\
Individual Citizens & 0.002 & 0.0179 & 0.911 \\
Portfolio Companies & 0.0057 & 0.022 & 0.759 \\
Strategic & 0.0014 & 0.0118 & 0.901 \\
Bank & -0.0226 & 0.0267 & 0.397 \\
Joint Test $\chi^{2}(5)$ & 1.049 & & 0.959 \\
\hline
\end{tabular}


Table 5. Estimation of Environmental Performance: EfFects of State OWnership and OWnership Concentration

\begin{tabular}{|c|c|c|c|c|c|c|c|c|}
\hline \multirow{2}{*}{ RHS Variable } & \multicolumn{4}{|c|}{ Model 1B Absolute Emissions } & \multicolumn{4}{|c|}{ Model 2B Relative Emissions } \\
\hline & OLS & Between & Fixed Ef. & Random Ef. & OLS & Between & Fixed Ef. & Random Ef \\
\hline Production / Assets & $\begin{array}{c}0.267 * * * \\
(0.042)\end{array}$ & $\begin{array}{c}0.330 * * * \\
(0.019)\end{array}$ & $\begin{array}{c}0.494 * * * \\
(0.154)\end{array}$ & $\begin{array}{c}0.295 * * * \\
(0.017)\end{array}$ & $\begin{array}{c}1.542 * * * \\
(0.332)\end{array}$ & $\begin{array}{c}1.989 * * * \\
(0.345)\end{array}$ & $\begin{array}{c}0.963 * * \\
(0.395)\end{array}$ & $\begin{array}{c}1.275 * * * \\
(0.139)\end{array}$ \\
\hline Lagged Profits / Assets & $\begin{array}{l}-0.874 \\
(0.617)\end{array}$ & $\begin{array}{c}-1.482 * * * \\
(0.334)\end{array}$ & $\begin{array}{c}-0.701 * \\
(0.425)\end{array}$ & $\begin{array}{c}-0.925 * * * \\
(0.152)\end{array}$ & $\begin{array}{l}-17.89 \\
(14.35)\end{array}$ & $\begin{array}{c}-51.97 * * * \\
(6.22)\end{array}$ & $\begin{array}{c}-3.33 * * \\
(1.63)\end{array}$ & $\begin{array}{c}-4.31 * * * \\
(0.675)\end{array}$ \\
\hline State Ownership (\%) & $\begin{array}{c}0.0123 * * * \\
(0.0043)\end{array}$ & $\begin{array}{c}0.0154 * * * \\
(0.0041)\end{array}$ & $\begin{array}{c}-0.0048 * * \\
(0.0020)\end{array}$ & $\begin{array}{l}0.0049 * \\
(0 . .0027)\end{array}$ & $\begin{array}{c}0.0023 \\
(0.0272)\end{array}$ & $\begin{array}{c}0.0144 \\
(0.0761)\end{array}$ & $\begin{array}{c}-0.0210 * \\
(0.0062)\end{array}$ & $\begin{array}{l}-0.0148 \\
(0.0137)\end{array}$ \\
\hline Concentration: Largest Shareholder & $\begin{array}{c}0.0016 \\
(0.0024)\end{array}$ & $\begin{array}{c}0.0028 \\
(0.0031)\end{array}$ & $\begin{array}{c}-0.0045 * \\
(0.0025)\end{array}$ & $\begin{array}{l}-0.0015 \\
(0.0020)\end{array}$ & $\begin{array}{l}-0.0024 \\
(0.0171)\end{array}$ & $\begin{array}{c}0.0201 \\
(0.0600)\end{array}$ & $\begin{array}{l}-0.0013 \\
(0.0066)\end{array}$ & $\begin{array}{l}-0.0025 \\
(0.0099)\end{array}$ \\
\hline Inverse Mills Ratio & $\begin{array}{c}0.552 * * * \\
(0.120)\end{array}$ & $\begin{array}{c}0.436 * * * \\
(0.149)\end{array}$ & $\begin{array}{c}1.108 * * \\
(0.444)\end{array}$ & $\begin{array}{c}0.622 * * * \\
(0.134)\end{array}$ & $\begin{array}{c}7.53 * * * \\
(2.18)\end{array}$ & $\begin{array}{c}7.16 * * \\
(2.77)\end{array}$ & $\begin{array}{c}8.25 * * \\
(4.09)\end{array}$ & $\begin{array}{c}9.66 * * * \\
(1.09)\end{array}$ \\
\hline Adjusted $\mathrm{R}^{2}$ & 0.298 & 0.504 & 0.786 & 0.291 & 0.129 & 0.214 & 0.974 & 0.096 \\
\hline $\begin{array}{l}\text { LM Heteroskedasticity Test } \\
\text { [significance level] }\end{array}$ & $\begin{array}{c}10.81 * * * \\
{[0.001]}\end{array}$ & $\begin{array}{c}0.579 \\
{[0.447]}\end{array}$ & $\begin{array}{c}73.98 * * * \\
{[0.000]}\end{array}$ & $\begin{array}{l}3.322 * \\
{[0.068]}\end{array}$ & $\begin{array}{l}5.62 * * \\
{[0.018]}\end{array}$ & $\begin{array}{c}37.40 * * * \\
{[0.000]}\end{array}$ & $\begin{array}{c}0.002 \\
{[0.964]}\end{array}$ & $\begin{array}{c}0.766 \\
{[0.382]}\end{array}$ \\
\hline $\begin{array}{l}\text { F-test of Individual Effects } \\
\quad \text { [significance level] }\end{array}$ & \multicolumn{4}{|c|}{$\begin{array}{l}6.52 * * * \\
{[0.000]}\end{array}$} & \multicolumn{4}{|c|}{$\begin{array}{c}78.10 * * * \\
{[0.000]}\end{array}$} \\
\hline $\begin{array}{l}\text { Hausman Fixed vs. Random } \\
\text { [significance level] }\end{array}$ & \multicolumn{4}{|c|}{$\begin{array}{c}10.36 \\
{[0.110]}\end{array}$} & \multicolumn{4}{|c|}{$\begin{array}{c}0.77 \\
{[0.979]}\end{array}$} \\
\hline No. of Firms / No. of Observations & \multicolumn{4}{|c|}{$463 / 1127$} & \multicolumn{4}{|c|}{463 / 1127} \\
\hline
\end{tabular}

Standard errors are noted inside parentheses; $p$-values are noted inside square brackets. $*, * *$, and $* * *$ indicate statistical significance levels of $0.10,0.05$, and 0.01 , respectively.

Each regression also includes an intercept term and year indicators. 


\section{TABLE 6.}

\section{Estimation of EnVironmental Performance: Effects of Industrial Categories}

\begin{tabular}{|c|c|c|c|c|}
\hline \multirow{3}{*}{ RHS Variable } & \multicolumn{2}{|c|}{$\begin{array}{c}\text { Model 1B } \\
\text { Absolute Emissions }\end{array}$} & \multicolumn{2}{|c|}{$\begin{array}{c}\text { Model 2B } \\
\text { Relative Emissions }\end{array}$} \\
\hline & & Random & & Random \\
\hline & Between & Effects & Between & Effects \\
\hline Production / Assets & $\begin{array}{c}0.345 * * * \\
(0.016)\end{array}$ & $\begin{array}{c}0.308 * * * \\
(0.015)\end{array}$ & $\begin{array}{c}1.942 * * * \\
(0.351)\end{array}$ & $\begin{array}{c}1.328 * * * \\
(0.140)\end{array}$ \\
\hline Lagged Profits / Assets & $\begin{array}{l}-1.689 * * * \\
\quad(0.297)\end{array}$ & $\begin{array}{l}-1.016 * * * \\
\quad(0.148)\end{array}$ & $\begin{array}{l}-49.37 * * * \\
\quad(6.49)\end{array}$ & $\begin{aligned}- & 4.49 * * * \\
& (0.689)\end{aligned}$ \\
\hline State Ownership (\%) & $\begin{array}{c}0.0003 \\
(0.0040)\end{array}$ & $\begin{array}{l}-0.0018 \\
(0 . .0027)\end{array}$ & $\begin{array}{l}-0.0158 \\
(0.0880)\end{array}$ & $\begin{array}{l}-0.0145 \\
(0.0139)\end{array}$ \\
\hline Concentration: Largest Shareholder & $\begin{array}{c}0.0034 \\
(0.0028)\end{array}$ & $\begin{array}{l}-0.0012 \\
(0.0019)\end{array}$ & $\begin{array}{c}0.0272 \\
(0.0615)\end{array}$ & $\begin{array}{l}-0.0014 \\
(0.0101)\end{array}$ \\
\hline Inverse Mills Ratio & $\begin{array}{c}0.575 * * * \\
(0.196)\end{array}$ & $\begin{array}{l}0.731 * * * \\
(0.162)\end{array}$ & $\begin{array}{c}16.3 * * * \\
(4.29)\end{array}$ & $\begin{array}{l}11.98 * * * \\
(1.22)\end{array}$ \\
\hline Adjusted $\mathrm{R}^{2}$ & 0.642 & 0.48 & 0.217 & 0.116 \\
\hline $\begin{array}{l}\text { LM Heteroskedasticity Test } \\
\text { [significance level] }\end{array}$ & $\begin{array}{c}0.996 \\
{[0.318]}\end{array}$ & $\begin{array}{c}7.830 * * * \\
{[0.005]}\end{array}$ & $\begin{array}{c}55.69 * * * \\
{[0.000]}\end{array}$ & $\begin{array}{c}7.07 * * * \\
{[0.008]}\end{array}$ \\
\hline $\begin{array}{l}\text { F-test of Individual Effects } \\
\text { [significance level] }\end{array}$ & \multicolumn{2}{|c|}{$\begin{array}{c}4.19 * * * \\
{[0.000]}\end{array}$} & \multicolumn{2}{|c|}{$\begin{array}{c}71.57 * * * \\
{[0.000]}\end{array}$} \\
\hline $\begin{array}{l}\text { Test of Industrial Dummies in RE } \chi^{2}(21) \\
\quad \text { [significance level] }\end{array}$ & \multicolumn{2}{|c|}{$\begin{array}{l}81 * * * \\
{[0.000]}\end{array}$} & \multicolumn{2}{|c|}{$\begin{array}{l}231 * * * \\
{[0.000]}\end{array}$} \\
\hline $\begin{array}{l}\text { Hausman Fixed vs. Random } \\
\text { [significance level] }\end{array}$ & \multicolumn{2}{|c|}{$\begin{array}{c}10.18 \\
{[0.117]}\end{array}$} & \multicolumn{2}{|c|}{$\begin{array}{c}1.70 \\
{[0.888]}\end{array}$} \\
\hline No. of Firms / No. of Observations & \multicolumn{2}{|c|}{$463 / 1127$} & \multicolumn{2}{|c|}{$463 / 1127$} \\
\hline
\end{tabular}

Standard errors are noted inside parentheses; p-values are noted inside square brackets. $*, * *$, and $* * *$ indicate statistical significance levels of $0.10,0.05$, and 0.01 , respectively. Each regression also includes an intercept term, year indicators, and 22 industrial indicators (for which the excluded category is the manufacturing of machinery n.e.c.) 
William Davidson Institute Working Paper 492

\section{APPENDIX \# 1}

Table A-1. Estimation of Environmental Performance as Measured by Individual Air Pollutants

\begin{tabular}{|c|c|c|c|c|c|c|c|c|}
\hline \multirow[b]{2}{*}{ RHS Variable } & \multicolumn{2}{|c|}{ Carbon Monoxide } & \multicolumn{2}{|c|}{ Sulphur Dioxide } & \multicolumn{2}{|c|}{ Particular Matter } & \multicolumn{2}{|c|}{ Nitrous Oxides } \\
\hline & Model 1A & Model 2A & Model 1A & Model 2A & Model 1A & Model 2A & Model 1A & Model 2A \\
\hline \multicolumn{9}{|l|}{ Pooled OLS } \\
\hline $\begin{array}{l}\text { Production / } \\
\text { Fixed Assets }\end{array}$ & $\begin{array}{c}0.031 * * * \\
(0.007)\end{array}$ & $\begin{array}{c}0.127 * * * \\
(0.046)\end{array}$ & $\begin{array}{c}0.006 \\
(0.014)\end{array}$ & $\begin{array}{l}-0.039 \\
(0.063)\end{array}$ & $\begin{array}{c}0.028^{* * *} \\
(0.006)\end{array}$ & $\begin{array}{c}0.165 * * \\
(0.070)\end{array}$ & $\begin{array}{c}0.196^{* * * *} \\
(0.056)\end{array}$ & $\begin{array}{c}1.173 * * * \\
(0.353)\end{array}$ \\
\hline $\begin{array}{c}\text { Lagged Profit / } \\
\text { Fixed Assets }\end{array}$ & $\begin{array}{l}-0.016 \\
(0.036)\end{array}$ & $\begin{array}{l}-0.516^{*} \\
(0.263)\end{array}$ & $\begin{array}{l}-0.056 \\
(0.339)\end{array}$ & $\begin{array}{l}-3.757^{*} \\
(1.983)\end{array}$ & $\begin{array}{l}-0.221 \\
(0.196)\end{array}$ & $\begin{array}{l}-8.254 \\
(7.714)\end{array}$ & $\begin{array}{c}0.026 \\
(0.095)\end{array}$ & $\begin{array}{l}-0.735 \\
(0.935)\end{array}$ \\
\hline Adjusted $\mathrm{R}^{2}$ & 0.045 & 0.021 & 0.001 & 0.011 & 0.032 & 0.029 & 0.47 & 0.393 \\
\hline $\begin{array}{l}\text { LM Heterosk. Test } \\
\text { [significance level] }\end{array}$ & $\begin{array}{c}1.45 \\
{[0.231]} \\
\end{array}$ & $\begin{array}{c}0.52 \\
{[0.469]} \\
\end{array}$ & $\begin{array}{c}11.96^{* * *} \\
{[0.001]}\end{array}$ & $\begin{array}{l}5.14 * * \\
{[0.023]}\end{array}$ & $\begin{array}{c}0.84 \\
{[0.358]} \\
\end{array}$ & $\begin{array}{l}53.2^{* *} \\
{[0.000]}\end{array}$ & $\begin{array}{c}1450 * * * \\
{[0.000]}\end{array}$ & $\begin{array}{l}228 * * * \\
{[0.000]}\end{array}$ \\
\hline \multicolumn{9}{|l|}{ Between Group } \\
\hline $\begin{array}{l}\text { Production / } \\
\text { Fixed Assets }\end{array}$ & $\begin{array}{c}0.027 * * * \\
(0.004)\end{array}$ & $\begin{array}{c}0.133 * * * \\
(0.028)\end{array}$ & $\begin{array}{c}0.000 \\
(0.016)\end{array}$ & $\begin{array}{c}0.014 \\
(0.135)\end{array}$ & $\begin{array}{c}0.038 * * * \\
(0.007)\end{array}$ & $\begin{array}{c}0.507 * * \\
(0.244)\end{array}$ & $\begin{array}{c}0.235^{* * *} * \\
(0.008)\end{array}$ & $\begin{array}{c}1.467 * * * \\
(0.054)\end{array}$ \\
\hline $\begin{array}{c}\text { Lagged Profit / } \\
\text { Fixed Assets }\end{array}$ & $\begin{array}{l}-0.051 \\
(0.068)\end{array}$ & $\begin{array}{c}-1.794 * * * \\
(0.528)\end{array}$ & $\begin{array}{l}-0.427 \\
(0.300)\end{array}$ & $\begin{array}{c}-14.86^{* * *} \\
(2.514)\end{array}$ & $\begin{array}{c}-1.184 * * * \\
(0.137)\end{array}$ & $\begin{array}{c}-48.86^{* * * *} \\
(4.538)\end{array}$ & $\begin{array}{l}-0.001 \\
(0.140)\end{array}$ & $\begin{array}{c}-3.826^{* * * *} \\
(0.993)\end{array}$ \\
\hline Adjusted $\mathrm{R}^{2}$ & 0.091 & 0.064 & 0.014 & 0.097 & 0.151 & 0.206 & 0.643 & 0.586 \\
\hline $\begin{array}{l}\text { LM Heterosk. Test } \\
\text { [significance level] }\end{array}$ & $\begin{array}{c}0.29 \\
{[0.592]}\end{array}$ & $\begin{array}{c}1.74 \\
{[0.187]} \\
\end{array}$ & $\begin{array}{l}37.3 * * * \\
{[0.000]}\end{array}$ & $\begin{array}{l}82.3 * * * \\
{[0.000]}\end{array}$ & $\begin{array}{l}150 * * * \\
{[0.000]}\end{array}$ & $\begin{array}{l}386 * * * \\
{[0.000]} \\
\end{array}$ & $\begin{array}{l}407 * * * \\
{[0.028]} \\
\end{array}$ & $\begin{array}{l}246 * * * \\
{[0.000]}\end{array}$ \\
\hline \multicolumn{9}{|l|}{ Fixed Effects } \\
\hline $\begin{array}{l}\text { Production / } \\
\text { Fixed Assets }\end{array}$ & $\begin{array}{c}0.061 * * * \\
(0.014)\end{array}$ & $\begin{array}{c}0.230 * * * \\
(0.048)\end{array}$ & $\begin{array}{l}0.091 * \\
(0.050)\end{array}$ & $\begin{array}{l}-0.028 \\
(0.132)\end{array}$ & $\begin{array}{c}0.023 \\
(0.020)\end{array}$ & $\begin{array}{l}-0.018 \\
(0.054)\end{array}$ & $\begin{array}{c}0.160 * * * \\
(0.033)\end{array}$ & $\begin{array}{c}0.648 * * * \\
(0.241)\end{array}$ \\
\hline $\begin{array}{l}\text { Lagged Profit / } \\
\text { Fixed Assets }\end{array}$ & $\begin{array}{c}0021 \\
(0.049)\end{array}$ & $\begin{array}{c}0.007 \\
(0.165)\end{array}$ & $\begin{array}{l}-0.216 \\
(0.197)\end{array}$ & $\begin{array}{c}-1.934 * * \\
(0.853)\end{array}$ & $\begin{array}{l}-0.104 \\
(0.081)\end{array}$ & $\begin{array}{l}-0.673^{*} \\
(0.392)\end{array}$ & $\begin{array}{c}-0.093 * * \\
(0.037)\end{array}$ & $\begin{array}{c}-0.599 * * \\
(0.281)\end{array}$ \\
\hline Adjusted $\mathrm{R}^{2}$ & 0.28 & 0.419 & 0.712 & 0.507 & 0.422 & 0.941 & 0.909 & 0.765 \\
\hline $\begin{array}{l}\text { LM Heterosk. Test } \\
\text { [significance level] }\end{array}$ & $\begin{array}{l}553 * * * \\
{[0.000]} \\
\end{array}$ & $\begin{array}{l}162 * * * \\
{[0.000]} \\
\end{array}$ & $\begin{array}{l}749 * * * \\
{[0.000]} \\
\end{array}$ & $\begin{array}{l}25.1 * * * \\
{[0.000]} \\
\end{array}$ & $\begin{array}{l}492 * * * \\
{[0.000]} \\
\end{array}$ & $\begin{array}{c}0.031 \\
{[0.861]} \\
\end{array}$ & $\begin{array}{l}154 * * * \\
{[0.000]} \\
\end{array}$ & $\begin{array}{l}4.98 * * \\
{[0.026]} \\
\end{array}$ \\
\hline \multicolumn{9}{|l|}{ Random Effects } \\
\hline $\begin{array}{l}\text { Production / } \\
\text { Fixed Assets }\end{array}$ & $\begin{array}{c}0.034 * * * \\
(0.004)\end{array}$ & $\begin{array}{l}0.152 * * * \\
(0.024)\end{array}$ & $\begin{array}{c}0.046^{* * * *} \\
(0.011)\end{array}$ & $\begin{array}{l}-0.038 \\
(0.082)\end{array}$ & $\begin{array}{c}0.029 * * * \\
(0.006)\end{array}$ & $\begin{array}{l}-0.005 \\
(0.054)\end{array}$ & $\begin{array}{c}0.187^{* * * *} \\
(0.004)\end{array}$ & $\begin{array}{c}1.110 * * * \\
(0.035)\end{array}$ \\
\hline $\begin{array}{l}\text { Lagged Profit / } \\
\text { Fixed Assets }\end{array}$ & $\begin{array}{l}-0.015 \\
(0.041)\end{array}$ & $\begin{array}{l}-0.351 \\
(0.236)\end{array}$ & $\begin{array}{c}-0.271 * * * \\
(0.092)\end{array}$ & $\begin{array}{c}-3.518 * * * \\
(0.771)\end{array}$ & $\begin{array}{c}-0.243^{* * *} \\
(0.059)\end{array}$ & $\begin{array}{c}-1.527 * * * \\
(0.352)\end{array}$ & $\begin{array}{l}-0.057^{*} \\
(0.030)\end{array}$ & $\begin{array}{l}-0.441 \\
(0.302)\end{array}$ \\
\hline Adjusted $\mathrm{R}^{2}$ & 0.045 & 0.02 & 0.005 & 0.011 & 0.032 & 0.014 & 0.469 & 0.392 \\
\hline $\begin{array}{l}\text { LM Heterosk. Test } \\
\text { [significance level] }\end{array}$ & $\begin{array}{c}1.186 \\
{[0.276]} \\
\end{array}$ & $\begin{array}{c}0.101 \\
{[0.750]}\end{array}$ & $\begin{array}{l}4.95 * * \\
{[0.256]} \\
\end{array}$ & $\begin{array}{c}3.11 * \\
{[0.078]}\end{array}$ & $\begin{array}{c}0.928 \\
{[0.335]} \\
\end{array}$ & $\begin{array}{l}39.6 * * * \\
{[0.000]} \\
\end{array}$ & $\begin{array}{c}1569 * * * \\
{[0.256]}\end{array}$ & $\begin{array}{l}311 * * * \\
{[0.000]} \\
\end{array}$ \\
\hline $\begin{array}{l}\text { F-test of Indiv. Eff. } \\
\text { [significance level] }\end{array}$ & $\begin{array}{l}2.35 * * * \\
{[0.000]}\end{array}$ & $\begin{array}{l}3.54 * * * \\
{[0.000]}\end{array}$ & $\begin{array}{l}10.4 * * * \\
{[0.000]}\end{array}$ & $\begin{array}{l}4.86 * * * \\
{[0.000]}\end{array}$ & $\begin{array}{l}3.59 * * * \\
{[0.000]}\end{array}$ & $\begin{array}{c}60.10 * * * \\
{[0.000]}\end{array}$ & $\begin{array}{l}19.5 * * * \\
{[0.000]}\end{array}$ & $\begin{array}{l}7.12 * * * \\
{[0.000]}\end{array}$ \\
\hline $\begin{array}{l}\text { Hausman FE vs. RE } \\
\text { [significance level ] }\end{array}$ & $\begin{array}{c}4.58 \\
{[0.101]}\end{array}$ & $\begin{array}{c}3.65 \\
{[0.162]}\end{array}$ & $\begin{array}{c}4.53 \\
{[0.339]}\end{array}$ & $\begin{array}{c}0.001 \\
{[0.926]}\end{array}$ & $\begin{array}{c}7.01 * \\
{[0.072]}\end{array}$ & $\begin{array}{l}4.437 * * \\
{[0.035]}\end{array}$ & $\begin{array}{c}3.867 \\
{[0.276]}\end{array}$ & $\begin{array}{c}3.94 \\
{[0.140]}\end{array}$ \\
\hline \# Firms / \# Obs. & $564 / 2173$ & $564 / 2173$ & $564 / 2173$ & $564 / 2173$ & $564 / 2173$ & $564 / 2173$ & $564 / 2173$ & $564 / 2173$ \\
\hline
\end{tabular}

Standard errors are noted inside parentheses; p-values are noted in square brackets.

$*,{ }^{*}, * * *$ indicate statistical significance at $10 \%, 5 \%, 1 \%$ respectively.

Each regression also includes an intercept term and year indicator variables. 
William Davidson Institute Working Paper 492

\section{APPENDIX \# 2}

\section{Granger Causality Tests}

In this appendix, we test the Granger causality between profits and emissions. Granger causality tests rely on the estimation of these two basic equations:

$$
Y_{t}=\alpha_{0}+\sum_{i=1}^{k_{1}} \alpha_{i} Y_{t-i}+\sum_{i=1}^{k_{2}} \beta_{i} X_{t-i}+\varepsilon_{t}
$$

and

$$
X_{t}=\gamma_{0}+\sum_{i=1}^{k_{3}} \gamma_{i} Y_{t-i}+\sum_{i=1}^{k_{4}} \delta_{i} X_{t-i}+\nu_{t}
$$

where $X$ denotes profits, $Y$ denotes emissions, the subscripts $t$ and $t-i$ denote the current and lagged values, and $\mathrm{k}_{1}=\mathrm{k}_{2}=\mathrm{k}_{3}=\mathrm{k}_{4}=\{1,2\}$ (i.e., we use lags of one or two periods).

We must address the fact that the presence of lagged values of the dependent variable on the right-hand side of equations (A1) and (A2) in a dynamic panel data framework can lead to inconsistent parameter estimates unless the time dimension of the panel is very large (Nerlove, 1967; Nickell, 1981; Keane and Runkle, 1992). Anderson and Hsiao (1981) propose using twice-lagged levels of the right-hand side variables as instruments. They also discuss the possibility of using lagged differences as estimates. However, Kiviet (1995) establishes the superiority of using twicelagged levels over lagged differences. Kiviet (1995) suggests an alternative approach that involves direct calculation of biases and correction of the least squares estimates. Simulation results in Judson and Owen (1999) show that Anderson-Hsiao estimators, while the least biased among the available alternatives, are considerably less efficient than the alternative proposed by Kiviet (1995). Unfortunately, the extension of Kiviet (1995)'s estimator to unbalanced panels, while conceptually 
William Davidson Institute Working Paper 492

possible, is computationally unfeasible. Fortunately, simulation results in Judson and Owen (1999, p. 13) also show that the bias problems are almost entirely concentrated in the coefficient on the lagged dependent variables, while biases in the coefficients of independent variables -- $\beta$ and $\delta$ in equations (A1) and (A2) respectively -- are "relatively small and cannot be used to distinguish between estimators [including OLS]". In sum, we elect to ignore the bias corrections in the Grangercausality tests for the following reasons. First, we are not interested in point estimates of the noted coefficients. Second, any correction for biases would result in a significant loss of efficiency that would damage our ability to assess the causal relationships. Third, the coefficient bias is most likely small. Fourth, the dynamic panel nature of the data greatly complicates the bias correction.

Depending on the specification of the time lag, we find that emissions never Granger-cause profits. The p-values of these tests are much higher than the conventional $10 \%$ level. On the other hand, profits Granger-cause emissions. The p-values of these tests oscillate around the $10 \%$ critical level. Therefore, given the mentioned bias in the coefficients, we argue that no causality link exists from emissions to profits yet the opposite link appears to exist.

Using a similar approach, we test the Granger causality between production and emissions. The results reveal that emissions never Granger-cause production yet production appears to Grangercause emissions, i.e, a link from production to emissions cannot be safely rejected.

Full econometric results for all of these Granger causality tests are available upon request. 


\section{DAVIDSON INSTITUTE WORKING PAPER SERIES - Most Recent Papers}

The entire Working Paper Series may be downloaded free of charge at: www.wdi.bus.umich.edu

CURRENT AS OF 8/14/02

\begin{tabular}{|c|c|c|}
\hline Publication & Authors & Date \\
\hline $\begin{array}{l}\text { No. 492: Effects of Ownership and Financial Status on Corporate } \\
\text { Environmental Performance }\end{array}$ & $\begin{array}{l}\text { Dietrich Earnhart and Lubomír } \\
\text { Lízal }\end{array}$ & Aug. 2002 \\
\hline $\begin{array}{l}\text { No. 491: Does Economic Uncertainty Have an Impact on Decisions to } \\
\text { Bear Children? Evidence from Eastern Germany }\end{array}$ & $\begin{array}{l}\text { Sumon Kumar Bhaumik and } \\
\text { Jeffrey B. Nugent }\end{array}$ & July 2002 \\
\hline $\begin{array}{l}\text { No. 490: The Reallocation of Workers and Jobs in Russian Industry: } \\
\text { New Evidence on Measures and Determinants }\end{array}$ & J. David Brown and John S. Earle & Aug. 2002 \\
\hline $\begin{array}{l}\text { No. 489: The Incidence and Cost of Job Loss in a Transition Economy: } \\
\text { Displaced Workers in Estonia, 1989-1999 }\end{array}$ & $\begin{array}{l}\text { Hartmut Lehmann, Kaia Phillips } \\
\text { and Jonathan Wadsworth }\end{array}$ & Aug. 2002 \\
\hline No. 488: Integration: An Empirical Assessment of Russia & $\begin{array}{l}\text { Daniel Berkowitz and David N. } \\
\text { DeJong }\end{array}$ & Feb. 2002 \\
\hline $\begin{array}{l}\text { No. 487: Dual Inflation under the Currency Board: The challenges of } \\
\text { Bulgarian EU accession }\end{array}$ & $\begin{array}{l}\text { Nikolay Nenovsky and Kalina } \\
\text { Dimitrova }\end{array}$ & July 2002 \\
\hline $\begin{array}{l}\text { No. 486: Worker Flows, Job Flows and Firm Wage Policies: } \\
\text { An Analysis of Slovenia }\end{array}$ & $\begin{array}{l}\text { John Haltiwanger and Milan } \\
\text { Vodopivec }\end{array}$ & July 2002 \\
\hline $\begin{array}{l}\text { No. 485: Do Schumpeterian Waves of Creative Destruction Lead to } \\
\text { Higher Productivity? Panel Data Evidence from Poland }\end{array}$ & Frederic Warzynski & July 2002 \\
\hline $\begin{array}{l}\text { No. 484: Labor Market Institutions and Restructuring: Evidence from } \\
\text { Regulated and Unregulated Labor Markets in Brazil }\end{array}$ & Jasper Hoek & July 2002 \\
\hline $\begin{array}{l}\text { No. 483: The Balassa-Samuelson effect in Central and Eastern Europe: } \\
\text { Myth or reality? }\end{array}$ & $\begin{array}{l}\text { Balázs Égert, Imed Drine, Kirsten } \\
\text { Lommatzsch and Christophe } \\
\text { Rault }\end{array}$ & July 2002 \\
\hline No. 482: Real Exchange Rates in Transition Economies & Boštjan Jazbec & July 2002 \\
\hline $\begin{array}{l}\text { No. 481: Labor Force Participation Dynamics in the Romanian Labor } \\
\text { Market }\end{array}$ & Alexandru Voicu & July 2002 \\
\hline $\begin{array}{l}\text { No. 480: Equilibrium Real Exchange Rates in Central Europe's } \\
\text { Transition Economies: Knocking on Heaven's Door }\end{array}$ & Balázs Égert & July 2002 \\
\hline $\begin{array}{l}\text { No. 479: The Impact of Minimum Wages on Wage Inequality and } \\
\text { Employment in the Formal and Informal Sector in Costa Rica }\end{array}$ & $\begin{array}{l}\text { Fatma El-Hamidi and Katherine } \\
\text { Terrell }\end{array}$ & Apr. 2001 \\
\hline $\begin{array}{l}\text { No. 478: Beyond Oaxaca -Blinder: Accounting for Differences in } \\
\text { Household Income Distributions }\end{array}$ & $\begin{array}{l}\text { François Bourguignon, Francisco } \\
\text { H. G. Ferreira and Phillippe G. } \\
\text { Leite }\end{array}$ & Feb. 2002 \\
\hline $\begin{array}{l}\text { No. 477: Participation Behavior of East German Women after German } \\
\text { Unification }\end{array}$ & Holger Bonin and Rob Euwals & July 2002 \\
\hline No. 476: Duration and Risk of Unemployment in Argentina & $\begin{array}{l}\text { Sebastian Galiani and Hugo A. } \\
\text { Hopenhayn }\end{array}$ & Oct. 2001 \\
\hline $\begin{array}{l}\text { No. 475: After, Before and During: Returns to Education in the } \\
\text { Hungarian Transition }\end{array}$ & $\begin{array}{l}\text { Nauro F. Campos and Dean } \\
\text { Jolliffe }\end{array}$ & Apr. 2002 \\
\hline No. 474: The Locking-in Effect of Subsidized Jobs & Jan C. van Ours & June 2002 \\
\hline No. 473: How Reform Worked in China & Yingyi Qian & June 2002 \\
\hline No. 472: An Economic Perspective on Russia's Accession to the WTO & Robert M. Stern & June2002 \\
\hline $\begin{array}{l}\text { No. 471: The Effects of Ownership Forms and Concentration on Firm } \\
\text { Performance after Large-Scale Privatization }\end{array}$ & Evzen Kocenda and Jan Svejnar & May 2002 \\
\hline $\begin{array}{l}\text { No. 470: Growth in Transition: What We Know, What We Don't, and } \\
\text { What We Should }\end{array}$ & $\begin{array}{l}\text { Nauro F. Campos and Fabrizio } \\
\text { Coricelli }\end{array}$ & Feb. 2002 \\
\hline $\begin{array}{l}\text { No. 469: Barriers to Investment by Russian Firms: Property Protection } \\
\text { or Credit Constraints? }\end{array}$ & Susan J. Linz & May 2002 \\
\hline No. 468: Job Satisfaction Among Russian Workers & Susan J. Linz & May 2002 \\
\hline $\begin{array}{l}\text { No. 467: Assessing the Problem of Human Capital Mismatch in } \\
\text { Transition Economies }\end{array}$ & $\begin{array}{l}\text { Viliam Druska, Byeong ju Jeong, } \\
\text { Michal Kejak, and Viatcheslav } \\
\text { Vinogradov }\end{array}$ & Mar. 2002 \\
\hline
\end{tabular}

